Anna Dybo

Institute of Linguistics, Russian Academy of Sciences; adybo@mail.ru

\title{
New trends in European studies on the Altaic problem
}

\begin{abstract}
The paper discusses several general problems of present-day historical Altaistics, taking as a reference point the critical evaluation of two large monographs by Martine Robbeets - one on the Altaic origins of the Japanese language (Robbeets, Martine. 2005. Is Japanese related to Korean, Tungusic, Mongolic and Turkic? Wiesbaden: Harrassowitz) and another on the evidence that comparative verbal morphology provides to validate the Altaic hypothesis (Robbeets, Martine. 2015. Diachrony of verb morphology: Japanese and the Transeurasian languages. Berlin: Mouton de Gruyter). Along with the analysis of the main methodological principles and some specific etymological decisions taken by the author, the paper also focuses on the critical discussion of certain assumptions that may be seen as typical of "anti-Altaic" researchers.
\end{abstract}

Keywords: Altaic languages, historical Turkology, verbal morphology, long-range comparison, history of the Japanese language, etymology.

After the Etymological Dictionary of Altaic Languages (EDAL) came out in 2003, accompanied by both positive (Blažek 2005; Miller 2004) and sharply negative (Vovin 2005; Stachowski 2005; Norman 2009; Georg 2004) reviews, it seems logical that the next step, instead of a Sturm und Drang-style gathering of additional material to confirm the updated reconstruction, should rather be a verification and cleanup of the already accomplished work. The author of these lines remains fully convinced (in fact, has always been convinced) that the first collection of Altaic etymologies with claims to a certain degree of completeness, published by S. Starostin, A. Dybo, and O. Mudrak more than ten years ago, should have not been called Etymological Dictionary of Altaic Languages, but rather something like Versuch eines etymologischen Wörterbuchs der altaischen Sprachen (the English language, to which etymologists are less accustomed, is possibly to blame; An Attempt or An Essay as the beginning of an English title is clearly better fit for a review of a voluminous dictionary than for the dictionary itself). Thus, as of this moment, reconstructions for both Proto-Turkic and Proto-Tungusic have been significantly corrected, and it is of crucial importance to incorporate these corrections within the general Altaic comparison. Likewise, it is also very important to include recent modifications done on Japonic (Japanese-Ryukyuan) and Koreanic reconstruction (of course, not without some critical reflections on such works as Miyake 2003; Bentley 2008; Vovin 2005-2009). And, obviously, in the light of the need for such updates, it is only natural that our attention should be drawn to two interconnected works by Martine Irma Robbeets, one of which came out very soon after the original publication of EDAL, and another one appeared only very recently. As a disciple of Sergei Starostin, on one hand, and a student of the Leiden school of comparative linguistics, on the other hand, M. Robbeets is trying to further develop Altaic studies after EDAL, bringing them to the general attention of European scholars and trying to overcome the mistrust with which "Altaic" is generally viewed today in Western scholarly communities, so that her work deserves serious attention (and critical evaluation) on the part of both anti- and proAltaicists. 
The first of the books by Robbeets (2005: Is Japanese related to Korean, Tungusic, Mongolic and Turkic?) has already been reviewed twice, in Georg 2009 and Vovin 2009. ${ }^{1}$ Georg's criticism of Robbeets 2005 often seems unfair and unrelated to the essence of the matter. A detailed disassembling of his arraignments would serve no purpose, since, in a significant number of cases, they are reduced to "juggling" the evidence - there is a clear impression that a certain presumptive ill will did not allow him to properly understand the text (as an example, consider this case: on p. 26, he exclaims, “...how a mention of Old Turkic (p. 17) can manage to only talk about the Orkhon inscriptions, sweeping the bulk of the Old Turkic literature under the rug, is incomprehensible..." - meanwhile, on p. 17 Robbeets simply writes that the earliest Turkic monuments are the Orkhon inscriptions; likewise, in the periodization table of the Turkic languages she correctly points out that the "ancient Turkic period" is the period of the pre-Mongol invasion texts). Therefore, I will only address here some of his more fundamental quibbles.

For one thing, Georg writes that Robbeets is wrong to not have examined G. Doerfer's reconstruction of Proto-Tungusic vowels, for the following reason:

...both Proto-Tungusic and Proto-Mongolic had the pairs * $\ddot{u}$ and $* \ddot{o}$. "Cognates" between both families show a surprisingly blurred picture of correspondences for these phonemes which can be remedied by the assumption that a great number of these (regarded as "old inheritance" by the Altaicists) were borrowed from Mongolic into Tungusic at a time when the original contrast had already been restructured ( ${ }^{*} \ddot{u}>{ }^{*} i$ in Northern Tungusic, ${ }^{*} \ddot{O}>{ }^{*} 0$ ). It is not expected that a work like Robbeets' would accept this at face value, but that it is discussed, or at least known, is well within the range of what can be expected here. ${ }^{2}$

But in fact, there are virtually no pairs of Mongolic-Tungusic cognates in the Altaic dictionary where Mongolic would show $\ddot{u}$ and Northern Tungusic would have $i$ (PTM * $\ddot{u}$ ) in the Altaic dictionary - if Georg tried to find a confirmation for his idea, he would have been seriously disappointed. Looking all over the database, I was able to find exactly zero cases of such a correlation in the case of PTM *i (that is, where there are no reflexes in South Tung. or Manchurian, only in North Tung.) and only four cases of PMo * $\ddot{u}$ : PTM * $\ddot{u}$ which, as far as the phonetic shape of the morphemes is concerned, could probably be explained by borrowing, but at least in the first two of these cases, such an explanation would not agree with the semantics of Mongolic and Tungusic words, namely:

- PMo *üli- 'to compare', üliger 'shape, form, model, story' (Mong. > Evk. ulgur 'tale, story' etc., see Doerfer MT 48) || PTM *ül(k)e- 'to measure; to understand';

${ }^{1}$ A third review is Kara 2007. It is written in a more amicable and conservative manner and contains a number of specific corrections to etymologies, which should be accepted at least partially, even despite some visible inexperience of this first-rate specialist in Mongolian studies when it comes to applying the comparative-historical method. We have also a negative but not very informative review from Knüppel 2006 (containing no examples; cf. also Knüppel 2013 with similarly uninformative comments on Blažek 2007), and two positive reviews with minor corrections from Blažek (2007) and Miller (2007).

2 In connection with this, the following quote from Vovin 1995 seems relevant: "The reconstruction of ProtoTungusic *ö (Benzing 1955, Doerfer 1978) is highly questionable: it seems to be based mostly on the Even vowel $\theta$, used as a transcription sign, for example in Tsintsius 1975-77, which is in fact a back vowel, not a front one, as explicitely stated in Tsintsius (1947: 17) and Novikova (1960: 48), the two most comprehensive grammars of the Ewen language". Although the general doubt on the validity of Doerfer's reconstruction is legitimate, the actual reasoning is transparently wrong: if a Tungusic sound is phonetically a back vowel, this does not necessarily mean that it is morphophonologically not a front vowel. Cf. examples in Dudkin 1995: 9: нөригə [nөrig6] 'grayling', көңгәлә [keygolo] 'pit, ditch', with morphophonologically front ə in non-initial syllables. 


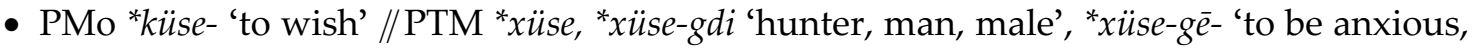
worry about smth.';

- PMo *sür- / *sur- 'to cry out; to sound, make noise (of wind)' || PTM *sür- 'to creak, screak; to shout, cry';

- PMo *türej 'boot-top' || PTM *türē-(kse) 'boot-top'.

In my doctoral thesis (Dybo 1992, partly published as Dybo 1996) this Proto-Tungusic entity is interpreted as the diphthong ${ }^{*} \ddot{u} j$ and confirmed by the existence of a back-vowel correlate ${ }^{*} u j$. An Altaic origin, with parallels in Mong., is offered: Alt. ${ }^{*} \ddot{j}>$ PTM ${ }^{*} \ddot{u}$ :

- PMo *möri 'shoulder' - PTM *müjre id.,

but the original height is preserved in such examples as PMo *tölgü 'prediction' - PTM *tolkin

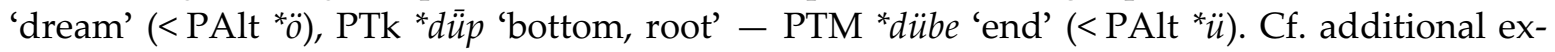
amples in EDAL (where traditional * $\ddot{u}$ stands in PTM for my ${ }^{*} \ddot{u} j$ ):

- PAlt *tújpè ( d-) 'hill, top', PMo *dobu / *döbe, PTM *dü- ( *düb-), PJa *(d)ípà;

- PAlt *iúse 'to grow, sprout', PTk *ös-, PMo *ös-, PTM *üse-;

- PAlt *iùte 'thick liquid', PTk *öt, PMo *öte-, PTM *üt-;

- PAlt *kiuurpe 'young (animal, fish)', PTk *körpe, PMo *körbe, PTM *xürbe;

- PAlt *kiùle 'to exchange, trade, hire', PTk *köle, PMo *kölü-sü, PTM *xül-;

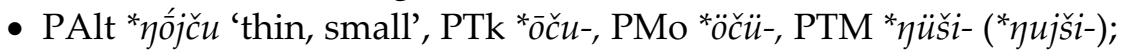

- PAlt *p'iùgV'to flay, cut', PMo *(h)öje-le-, PTM *püg-;

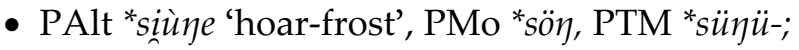

- PAlt *tốj- 'four', PTk *dôrrt, PMo *dör-ben, *dö-čin, PTM *dügin.

For another thing, regarding the Turkic issue of zetacism / rhotacism and its importance for the Altaic hypothesis, Georg is trying to be much more radical than his predecessor Doerfer (who - in my opinion, quite correctly - used to state that “Z/S plays no role!" (Doerfer 1988). Actually, his main argument here is a reference to Georg 2003: 436, which examined an alleged case of ${ }^{*} z$ to $r$ development in Chuvash pir 'linen' (cf. Common Turkic böz < Arabic bazz), but this example should be rejected: even if, ultimately, this is indeed a borrowing into Chuvash from Arabic, it still cannot be a reflex of Turkic *böz because the vowels do not match - see SIGTYa 2006: 173-179 (Chuvash erne 'Friday, week', also cited there, generally reflects another consonant, namely, Common Turkic $-\delta$-, see Fedotov 1996, 2: 480-481).

Another unjust criticism of Robbeets is encountered on p. 54:

Regular correspondences for initial CVC sequences: we have not mentioned this before, but, frankly, the present reviewer has never seen anybody in historical linguistics explicitly defend a principle which confines the area where sound correspondences are to be sought to the initial CVC part of words and which, consequently, would represent carte blanche for ignoring any other part of any word involved in any "etymology" entirely as uninteresting. In fact, such a "principle" can only be interpreted as an attempt to lower the standards which etymologies have to pass before acceptance and, thus, to ease the task of justifying the proud "Yes" on which the whole edifice of this book was palpably erected in the first place.

In fact, however, Robbeets is entirely correct, since the "initial CVC part" in application to the Altaic languages should in all likelihood be considered a "root". These languages are not prefixal, and their roots tend not to be lengthy, so the segmentation rests upon a reasonably 
logical foundation. In Indo-European linguistics, for that matter, this principle was almost certainly taken as a basis (cf. Benveniste's "root determinatives"), and there is no reason why at least for the initial phase of work on Altaic etymology it could not be accepted, based on somewhat similar grounds.

This list of observations could easily be enlarged, but on the whole, all these anti-Altaic arguments can be summarized by referring to a Russian one: на всякий чих не наздравствуещься ("you won't have enough 'bless you'-s for every sneeze”). It is certainly true that antiAltaicist comments on specific etymologies often contain valid points (although ultimately, my personal experience of evaluating them does not significantly decrease the total number of possible Altaic cognates). However, general complaints on various aspects of the reconstruction, such as the referral to Doerfer's views on PTM vocalism cited above, or the assumption that word-initial opposition of voiceless and voiced plosives in Proto-Oghuz is secondary (below I will refer to my own analysis; for dentals, see Dybo 2007 and a shorter version in Dybo, Starostin 2007), almost always turn out to be based on some systemic methodological error.

Concerning the review of Vovin (2009), I prefer to refrain from discussing it altogether. It is even more misrepresenting of Robbeets' achievements than Georg's, and, furthermore, is written in an unacceptable style, one that brings to mind the beginning of Vovin's own reply (Vovin 1995) to Karl Krippes' review of S. Starostin 1991 ("First of all, the tone of review can hardly be called academic. It rather reminds me a bazaar discourse with statements like 'data which he allegedly collected', 'Starostin did not have a good idea' etc.").

Instead, let us proceed to the actual discussion of Robbeets' work itself, beginning with the first monograph (2005). Although more than ten years old, this is where she provides her own system of phonetic correspondences, without which, of course, no further talk on language relationship is possible; the same analysis, for the most part, provides the foundation for the second, more recent, study.

As stated in the preface, the ideological position of the author seems to be almost perfect (including, among other things, her views on the problem of mixed languages, as well as the call for joint efforts between specialists in different languages). Naturally, archaeological (not to mention geographical) evidence can neither prove the relationship of the Altaic languages nor disprove it: language relationship is a purely linguistic concept, proven by purely linguistic methods - and it must be noted that (despite Georg's and Vovin's reproaches) Robbeets does not actually claim that she provides such a strict proof, but she does make it clear that, considering all available evidence, assumption of a Turkic-Japanese (or Tungusic-Japanese, etc.) relationship is more likely than, say, the assumption of a Turkic-Mayan (or TungusicMayan) relationship.

I can agree with the critics of Robbeets that her trust in the ability of genetic and archaeological data to prove or disprove something in the field of language history is clearly excessive. To begin with, archaeological evidence is always incomplete (one cannot be sure that even within such a relatively small and well-explored territory as Japan every archaeological site has been discovered and excavated); the criteria according to which several archaeological findings are grouped together as parts of one archaeological culture are not always explicable and often quite impressionistic; finally, the parameters of ethnic/linguistic identification of archaeological cultures remain rather poorly developed (see, e. g., Roberts \& Vander Linden 2011). As for genetics, it is well known that one should never expect any direct correlation between genes and language (as an example, cf. two cases when the correlation between genes, language, and geography is directly inverse, described in Balanovsky et al. 2011; Kushniarevich et al. 2015). Situations when genetic and archaeological data are in solid agreement within the framework of a simple historical / linguistic scenario are essentially due to random luck. 
Consequently, the circuit scheme on p. 39 ("a working model for the relationship between Japanese, Korean and Tungusic") raises some questions - above all, concerning such entities as "Macro-Tungusic" and "South-Tungusic", denoted as the consecutive ancestors of Koguryo and Paekche. It cannot be assumed that archaeologists writing about the "South Tungusic" migration to the Korean peninsula have anything specifically linguistic in mind - just as archaeologists studying data on Western Siberia care very little about linguistic accuracy when writing about the "Ugric-Samoyed" cultures or about settlements of "Ugric-Samoyeds", a unity which never existed in the linguistic sense (cf. Borodovskiy 2001 etc.).

In regard to research methodology as it is explained by the author, I have an important remark on the warning against relying on the so-called "nursery words". It seems that assignment of any given word to that category should not automatically lead to its complete exclusion from comparison and reconstruction (see G. Starostin 2009: on a desirable diachronic approach to these phenomena); rather, one should keep in mind that this lexical group is subject to frequent borrowings from a special type of "infant-adult pidgin". The same approach is valid for cases of onomatopoeia, since different languages may have different secondary mechanisms of vocabulary onomatopoeization (see, e. g., Dybo 2004).

The assumption about phonological universals in pronominal morphemes, proposed by J. Nichols (1992: 261-62, 266-67; also referred to in Nichols 2014), is referred to in a neutral tone, even if the notion is transparently absurd (and the same applies to case markers as well). In synthetic languages grammatical markers usually have a simpler phonetic structure than stems, and a system of, for instance, monosyllabic CV-type markers is much easier to perceive as subject to phonological universals, just because the number of such combinations is automatically more limited than, e. g., CVCV. The point that Northwest Caucasian languages, despite their phonetic complexity, prefer short and simple phonemic sequences like $s a-, w a-, d a-$ for their pronouns, is well made, but much more important is the fact that the only other language family in Eurasia that shares a phonetically similar pronominal system is Northeast Caucasian - an argument that agrees far better with a scenario of their genetic relationship than with anything that has to do with a mystical system of "phonological universals". The same principle of observing systemic isomorphism in pronominal systems should naturally work for Altaic as well.

Turning now to issues of phonetic reconstruction, it must first of all be noted that Robbeets' discussion of the Proto-Japanese reconstruction shows that this field, unfortunately, still has not properly progressed from a methodologically primitive stage. Thus, reconstruction of a special series of Proto-Japanese voiced consonants (discussed on p. 53-54) is essentially based on Japanese "doublets", i. e. words that have similar meanings but differ phonetically by the presence or absence of a certain consonant in word-initial position. However, if there are no attempts to find at least some sort of complementary phonetic distribution of these variants (and, apparently, there is no such distribution), such a reconstruction is methodologically impossible; in my opinion, the author discusses this issue with unjustified seriousness.

Concerning the origin of the so-called "triangle sound" in Middle Korean from lenition: despite the fact that, as the author notes correctly, there is a significant number of exceptions to the lenition rule, her rejection of traditional solutions that interpret the sound as a palatal nasal *n looks strange. "Internal reconstruction", argued for in the works of S. Martin, is naturally important, but it can hardly be satisfactory with such a high percentage of unexplained exceptions. Verner's law, which Martin (1996: 58) mentions as an example of the importance of priority of internal over external reconstruction, is convenient precisely because it managed to explain multiple exceptions to older rules; in contrast, the "lenition law" has only served to multiply the number of such exceptions. 
It does not seem productive to assume that all cases where some of the experts hold different views on some problem should automatically be considered uncertain and the respective material should be excluded from analysis - a somewhat apprentice-like approach, in my opinion. It is true that historical materials on Japanese and Korean are quite complex for an outsider; on the other hand, application of the comparative-historical method within these groups by Koreanists and Japanologists has often remained (at least, until recently) questionable. Sometimes, these works do not show a clear understanding of the difference between the data of a written monument and a reconstruction; sometimes, no adherence to the basic principle that phonetic laws should not have unexplained exceptions. And internal reconstruction, while an important addition to the method as a whole, should always be treated with caution - one should always remember that the deeper it is, the less material is there to confirm the rule and, consequently, the less reliable are the results that you end up with. This reliability may be enhanced if external check over a number of equiprobable alternatives is introduced, making external comparison a logical (and sometimes necessary) wrap-up for internal reconstruction. Overall, conflicting expert judgments on complex situations should necessarily be compared in terms of strength of their argumentation, before the situation is relegated to the unreliable "gray area" of the reconstruction.

The Tungusic reconstruction is presented with some inaccuracies. Most significantly, it is not true that $\mathrm{V}$. Tsintsius really reconstructed palatal consonants ( $m^{\prime}, b^{\prime}, s^{\prime}, t^{\prime}$, etc.), but did not reconstruct diphthongs (p. 68). Tsintsius did reconstruct diphthongs; and cf. Tsintsius 1949: 210-214, where it is only stated that consonants in the palatal affricate series $-\check{c}, \check{z}$ (also $n^{\prime}, j$ ) - in some Tungusic dialects are, instead of affricates, realized as palatal explosives $-t^{\prime}, d^{\prime}$. Apparently, the author was misled by Benzing's statement (Benzing 1955: 40) that, following Tsintsius' logic in reconstructing palatal * $n$ ', it would also be possible to reconstruct other consonants as palatalized (“...aber dann müßte man wohl auch * $b$ '- (tg.

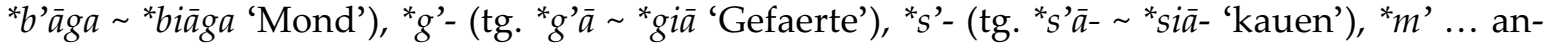
setzen"). Furthermore, Benzing indicates that the data are too scarce to agree upon a final decision; but today, with the publication of SSTMYa and other Tungusic dictionaries, this problem has largely been remedied, and it is now clear that regular reflexes of vocalic diphthongs do not allow us to interpret all cases of palatal * $n$ ' as secondary developments before an old diphthong or $* i$.

Regarding the RTR-harmony in Proto-Tungusic see below (p. 96 of this paper).

Robbeets' Mongolic reconstruction is taken directly from N. Poppe, without taking into consideration any amendments, including without distinction ${ }^{*}-\gamma^{-}$(or ${ }^{*}-h-;>0$ in modern Mongolic languages) and ${ }^{*}-g-(>-\gamma-/-g$ - in modern Mongolic languages) and without account for Vladimirtsov's rule $\left({ }^{*}-\gamma->-\gamma-/-g\right.$ - if a form contains another ${ }^{*}-\gamma$ - or a diphtongue). It should be noted that distinction between these two phonological entities, well reflected in the spelling of Sino-Mongolian documents, is now customary to Mongolian studies (cf. Janhunen 2003). The decision to reconstruct ${ }^{*} p$ - in Proto-Mongolic is a simplification; contrary to the opinion that S. Georg defended in his review, and in accordance with H. Nugteren (2013), we can be sure that actual Mongolic data calls for the reconstruction of ${ }^{*} h$ - rather than ${ }^{*} p$-; the development from ${ }^{*} h$ - to $f$ - (as well as to the palatal fricative) in South Mongolic languages is clearly due to vocalic context, cf.:

- *hunïn 'smoke' > Middle Mongol hunin, Dagur xony, Monguor funi / xuni, Bao'an fune / hone, Dongxiang funi. (Nugteren 2013: 364).

- *hinie- 'to laugh' > Dagur xina:d-, Monguor śine-, Bao'an śine- / xine-, Dongxiang śinie-. (Nugteren 2013: 357). 
- *hargal 'dung; dried cow dung (used as fuel)' > Middle Mongol haryal, Dagur xaryal,

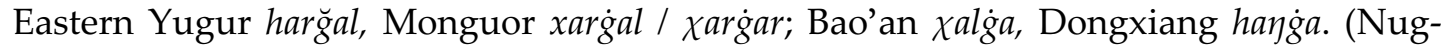
teren 2013: 350).

Contrary to the author's statement, Poppe's reconstruction of PMo * $\beta$ (Poppe 1955: 99) is not due exclusively to external comparisons - it is primarily based on the alternation $b \sim \gamma$, observed in certain Mongolian stems. Finally, the description of Mongolian vowel harmony, for some reason, does not mention any interpretations of it in the spirit of RTR (see, for instance, Svantesson 1985).

The PTk table contains some transparent mistakes. If this is a zetacist reconstruction, then where is ${ }^{*} l_{2}$ ? Johanson 1998 (as a source of data) is not to blame, because on p. 95 he does not present a complete table - his reconstructions are in the text itself (where, incidentally, there is also *h-, reconstructed based on Khalaj data, but not mentioned in the table, even though it is discussed on the same page of the book under review); however, on pp. 104-105 he explicitly interprets the respective prototypes as $r^{i}$ and $l^{i}$. [The explication of ${ }^{*} l_{2}<{ }^{*}-l C$ - in ProtoTurkic, with a reference to Street 1980: $78-79$, is not valid: ${ }^{*} l_{2}\left(\sim{ }^{*}\right)$ is an entity reconstructed based on correspondences between Common Turkic and Chuvash, with *- $l C$ - as a probable Altaic prototype for it (the presumed ${ }^{*}-l \check{c}^{-}$is reflected in Chuvash as $-s_{-}^{-}$, which is a common reflex for Turkic ${ }^{*} \check{c}$ and not for ${ }^{*} l_{2} /{ }^{*} \check{s}$ )]. The discussion of zetacism/rhotacism is presented in an oversimplified manner, without, for instance, any mention of "Helimski's rule" (see Helimski 1986 a, b, Dybo 1995a) and O. Mudrak's observations on the correspondences between Chuvash and Common Turkic (see, e. g., SIGTYa 2006: 27-40). Incidentally, Salar is by no means "a dialect of Uigur" (p. 75), since it is really an Oghuz language.

Concerning the problematic issue of whether initial voiced stops are to be reconstructed for Proto-Turkic, Robbeets resorts to the completely improper principle of "majority wins", for which she has been repeatedly blamed by Georg, and in this case I am forced to agree with his criticism. Such a principle simply does not exist in comparative linguistics: if 20 languages that belong to a certain family do not show a particular opposition, but the 21st does, it has to be reconstructed for the protolanguage - unless one is able to formulate a special rule of secondary positional distribution.

Robbeets' stance on this issue is mainly dependent on G. Doerfer's works, in which he opposed the separate reconstruction of voiced stops because of considerable variation in reflexes as well as the innovative nature of Oghuz voicing, since, presumably, Persian borrowings into Oghuz languages had also undergone such voicing. Concerning the first argument (variation in reflexes), it would have been advisable to become acquainted with the analysis of Oghuz reflexes in Dybo 2005, as well as in SIGTYa 2002: 68-72, where it was shown that the alleged variation is actually much more rare than advertised, and that most of such cases can be regularly explained. (Incidentally, even some of Robbeets' own examples of variations contain important omissions: thus, she writes "we find Tk göm- and Tkm. göm- 'dig' with a voiced reflex, while Azerbaijani köm- 'dig' has a voiceless reflex”, but cf. Azeri gömmak (rude, colloq.) 'to dig earth' in ARS 2006: 2, p. 275). As to voiced consonants in borrowings, here Robbeets cites, for example, Doerfer TMN: 3, 616, where it is supposed that PTk *gäne 'tick' is a borrowing into Proto-Oghuz from Persian kana id.; however, in the same book Doerfer cites a Classical Persian text from the 16th century, where it is said that qurād (Arabic 'ticks') in Turkic are called kene, and notes that this citation speaks in favor of a Turkic origin of the word. In general, Doerfer's conjectures about Iranisms in Turkic should be taken with a dose of caution: the origins of the Persian language are well studied, and a large number of Persian words have reliable etymologies that usually make it evident if the word is original or borrowed. In order to 
state with confidence that a certain Turkic word was borrowed from Persian, it would be required to find a suitable Iranian etymology for this word. However, etymologization of 'tick' on Iranian grounds is somewhat problematic.

Thus, J. Edelman (ESIYa: 4, 208) decisively lists the Persian word among the derivates of the Proto-Iranian verb *kan- 'to dig':

The words for 'tick', 'mosquito' and other biting, penetrating, and clinging insects can be classified here (with the patterns *kana-ka-, *kana-ci- etc.): Classic Persian kana, Tajik kana 'tick, bedbug' (< *kana-ka-), Pashto kunáy (masc.) 'tick (on dogs, sheep)' (<*kana-ka), but Pashto kana 'tick' - borrowed; Shugni čangin 'fly'; Sarikoli kawa, Yazgulami kenj 1) 'moth', 2) 'flour moth' < *kana-či-; Wakhi kakbing 'mosquito' - on the cognation of these words with Tajik kana see [ESWYa: 215]. Wakhi kwond 'tick' also belongs here [ESWYa: 214]”.

Steblin-Kamensky, in his Etymological Dictionary of Wakhi Language (ESWYa: 214) sticks to the same opinion:

[Wakhi] kwand 'tick'; Wakhi-Tajik xamandák, kana. Morgenstierne compares with Pashto kunáy 'tick (on dogs,

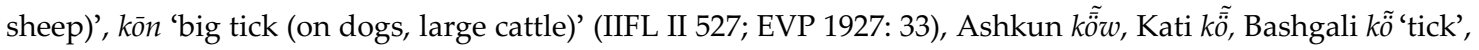
'louse' < Old Indian kuṇa- (CDIAL 3255); cf. also Wakhi xamandák 'ovine tick', Sanglechi xamándak 'tick', Badakhshani, Kabuli xamanduk, Persian, Tajik kana 'tick' (Turk.? - Doerfer TMN III 1653). Buddruss 277: to Persian káv-idan 'to dig, excavate'.

Indeed, in Mgst. IIFL: II, 527 we find: "[Wakhi] ku'wend L sheep tick. - Cf. Psht. kūnai (EVP, s.v. kōn)". But it is evident that if we stick to the comparison of Wakhi and Pashto words, they cannot be considered as a match for the Persian word because of phonetic reasons. In the old edition of the Etymological Dictionary of Pashto (Mgst. EVP 1927 : 33) we find: "kōn, kūnai 'a large species of tick or louse, infesting dogs and cattle'. - B. kōnyā'k. - Etym.

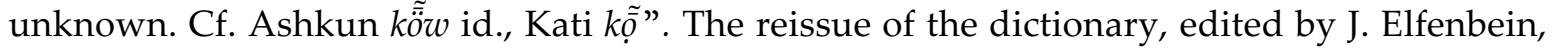
D. N. MacKenzie and N. Sims-Williams, directly states: "kon m. a large tick infesting animals. The $-n$, requiring old ${ }^{*}-r(V) n$ or ${ }^{*}-s h n-$, rules out connection with Prs. kana" (Mgst. EVP 2003: 23). On the other hand, we know of the Sanskrit word kuna 'a kind of insect living in clothes' (Monier-Williams: 289), clearly related to the Dardic words mentioned by Morgenstierne.

Thus, Persian kana 'tick' may theoretically be a verbal derivative, yet the word is properly recorded only in New Persian, with no earlier fixations. East Iranian forms that have been compared with it cannot be judged as proper etymological cognates - they either correspond to Skr. kuna, or represent borrowings from its Dardic relatives. However, all the problems connected with the tentative Iranian etymologization of the Persian word can be resolved by assuming instead that it is really a Turkism.

I have analyzed all three examples that Doerfer cites for the alleged voicing of ${ }^{*} t$ - in Persian borrowings in Proto-Oghuz in the introduction to Dybo 2007; here I will reproduce the same analysis for English readers.

In Doerfer 1971: 276 we find:

... the development $t->D$ - > $d$ surely is secondary in Oghuz... The above progression can be shown, among other things, by the development of old loanwords in Oghuz; e. g., Indian tōbra 'bag' (Turner 5972) became P. tōbra, the modern Osmanlı dorbacık (TM headword 947). Here $d$-is apparently secondary. The same holds true for P. tag்ār 'vessel' > Osmanlı dağarcık (TM headword № 905). 
The weakness of such a conclusion from the comparative point of view is quite transparent; moreover, not being a competent etymologist of Iranian material (even brilliant knowledge of Classical Persian is not sufficient for this purpose), G. Doerfer finds himself helpless in determining such loanwords (which certainly could not be appreciated by his anti-Altaicist colleagues - specialists in individual language families that constitute Altaic). Thus, he mentions Pers. tōbra 'bag, bucket bag' (in early sources mainly 'horse bucket bag'), estimated as an unequivocal Turkism, e. g., by such an trustworthy etymologist of Iranian data as R. Tsabolov (see Tsabolov KES 2, 214) as an originally Iranian form. Curiously, however, in an earlier publication (Doerfer TMN: II, 594) Doerfer is much more cautious about the etymology of this word, speaking only of its Indo-Aryan connections, which can be confirmed by referring to Turner, № 5972. But it is important to note that Turner's dictionary was not conceived as a reconstruction of Indo-Aryan lexicon (only Mayrhofer IA comes close to actually realizing this idea, although, incidentally, these particular words are not found in that edition); rather, the idea was to represent the Indo-Aryan lexical data as completely as possible in a well-classified manner. Therefore, numerous Modern Indian innovations were included along with archaic forms, among which, undoubtedly, we find the data cited by Doerfer.

Under № 5972, in particular, we find a reconstructed Proto-Indo-Aryan form *tōba 'bag' (a form certainly not attested in either Ancient or Middle Indian periods) with such Modern Indian reflexes as Bengali to 'pleat' and, supposedly a derivative noun with the diminutive suffix - $d a$, Lahnda țorā 'a bag hanged around a hand of bananas', Punjabi tora ' 'wallet', Kumaoni toro 'bag, especially for rupees', Bengali, Oriya, Hindi torāa 'leather wallet' (> Nepali torāa), Gujarati toṛ, Marathi toḍ̄ 'bag'; Bengali torā 'wallet' (from Bihari?). In support of his hypothetical Indo-Aryan reconstruction, Turner cites:

a) under question: Skr. țōpara- 'little bag', which, first of all, does not phonetically correspond to Modern Indian forms, and, second, is an obviously late "Sanskritization" of a Modern Indian word whose only attestation is in the text of Dhūrtasamāgamana, a low-genre comedy ("Gigolo's Promenade"), written in the 14th - 15th centuries A. D., by which time Turkisms in Indo-Aryan were perfectly possible;

b) a hypothetical Proto-Iranian *tübraka-, reconstructed by himself and based on Persian tōbra and Pashto tūbra (where the Pashto form is a transparent borrowing from Persian), East Baluchi thīray (borrowed into Brahui as tūra), Baxtiyari turba, Kurdish tūrik. These Iranian forms are clearly split into two groups: first, Persian tōbra, Baxtiyari turba and forms that could be borrowed from Persian, or directly from Turkic; second, East Baluchi thìrar and Kurdish $t \bar{u} r, t \bar{u} r a(\mathrm{~m}$.$) 'bag', 'tote bag' (tūrik - the form of the indirect case); in Tsabolov KES 2, 150$ even more forms belonging to the same etymon are listed, such as Luri türa 'bucket bag', 'pouch made of cloth', Semnani tūra 'bucket bag', 'pouch for pressing sesame oil', Lasgerdi, Sangisari tūre, Shamirzadi türe 'bucket bag', Sorxei türî 'bucket bag', 'pouch for straining (cottage) cheese'. It is fairly clear that this second group of forms goes back to Iranian (more precisely, Proto-West Iranian) ${ }^{*} t \bar{u} r a$. Kurdish and Baluchi forms could be descended from * $t \bar{u} b r a$, since in these languages $-b$ - in clusters $>-w$ - (Tsabolov OIF 91, 92, 81; Rastorgueva 1990: 184), but in other languages $-b$ - would have been preserved, cf. the reflexes of Ir. *abra 'cloud': Kurdish awr, Lasgerdi, Sangisari abr, Sorxei obr, Semnani abr, Baluchi West. aur, East. haur (Rastorgueva, Edelman: 2, 74).

For these reasons, regular etymological analysis does not allow to reliably reconstruct an Indo-Iranian entity in this case. Yet, astonishingly, Doerfer (TMN), referring to Turner's dictionary, even voices the idea that the Persian word may be derived from Indian tōbra, although Turner clearly states that, on the contrary, Punjabi and Hindi tobra (from which, in turn, are borrowed Bihari tobrẹa, Gujarati tobṛ, Marathi tobrā) is a Persian loanword. 
What is even more interesting is that in Proto-Oghuz this word may not have actually undergone voicing of the initial consonant. Turkic forms that are relevant for the reconstruction of the initial dental sound include: Turkish, Gagauz, Azeri torba, Turkmen tōrba; Old Osmanli (since the 14th c.) tobra, torva, also topra in one text from the 15th c. (TS: 3, 3824-3826); PTk *tōrpa or rather *topra (rare cluster in a Turkic root that undergoes metathesis, cf. *topra- $k$ 'soil, dust', Western Yugur durvaq, Azeri torpaG, Khalaj turpaq; TMN: II, 592-6, VEWT: 490). Cf. also Hung. turba 'bucket bag', attested since 1528 (thwrbam); contrary to MNyTESz: III, 1002, hardly from Osmanli torba, since the form had already been affected by the rule of transition from Old to Modern Hungarian, namely, $\bar{o}$ borrowed as Old Hung. $\bar{u}>\bmod$. $u$; hardly of Cuman-Pecheneg origin (cf. CCum. topra, i. e. still without the voicing of $-p-$ ), but, perhaps, late Bulgar? If the Hung. word really originates from Danube Bulgar, then the original word is Proto-Turkic; otherwise, it should be considered Common Oghuz-Karluk-Kipchak. Khalaj tọrba (D-T: 207) is a borrowing from Azeri (cf. the absence of vowel length).

A possible Altaic etymology is Proto-Altaic *toojrá 'a kind of vesssel' (PMo *torku 'tub, barrel; leather bucket' (Mong. > Turkmen torka 'bucket bag'), MKor. *tājá, PJap. *tàrápì 'trough' (Martin: 246, EDAL: p. 1391); PTk ${ }^{*} T A r$ 'pontoon, raft, boat', compared in the original EDAL etymology, should in this case be rather compared to PAlt *tiárko 'a kind of carriage', PMo *terge, PTM *turki 'dog-sledge', MKor. *tắrkó 'light carriage'. The provenance of "Modern Osmanli dorbacık", mentioned in Doerfer 1971, remains unclear. In contemporary dictionaries of Turkish, both literary and dialectal, this form is not attested. However, in TMN: II, 593 (which Doerfer refers to in the citation of this form in Doerfer 1971) we find "dopracuq 'ein kleiner Sack' (vielleicht 14. Jh.)” with reference to Vámbéry 1901: 162. This is, in fact, a form from an old Anatolian document (14th century), and it should be noted that these texts show highly specific orthographic systems, which allow, in particular, substantial variation in the recording of initial dentals; cf. the distribution of forms with $d$ - and $t$ - (Arabic emphatic $t$, used in words with back vowels) in "Kalila and Dimna", also from the $14^{\text {th }}$ century (Zajączkowski 1934):

- 'dust': dopraq - 5 times; topraq - 3 times (with Turkish toprak, Gagauz toprak, Azeri torpag, Turkmen, Khorezm-Oghuz topraq, Tuvinian do'vuraq, Tofa to'praq, PTk *topyrak < PAlt *t'ăpo $(r V)$, PMo *toyurag id., PTM *tap- 'to get dirty');

- 'to hold': dut- - 175 times, țt- - 1 time (with Turkish tut-, Gagauz tut-, Azeri tut-, Turkmen tut-, Tuvinian $t u^{\prime} t-/ d u$ 'dar, Tofa $t u^{\prime} t-$, PTk ${ }^{*} t u t-<$ PAlt ${ }^{*} t^{*}[u] t{ }^{*} V$, PMo todka- 'to delay', PTM *tuta- 'to stay').

Thus, one isolated case of a certain spelling cannot be accepted as relevant testimony of phonetic aberration until the exact manuscript is determined and the statistics of spellings with $d$ - and $t$ - for every morpheme in this manuscript is calculated - only in this manner can we restore the rules (or, more accurately, preferences) applied by individual scribes to the corresponding characters. After this, the forms are to be compared with contemporary (including dialectal) data, and only then we can proceed to meaningful hypotheses both on the phonetic meanings of the characters and on the dialectal identification of the scribe. Such philological research should undoubtedly be conducted for Old Anatolian and Old Osmanli texts; until then, judgements based on individual forms extracted from particular manuscripts will remain unsubstantiated. This statement pertains to all examples from Doerfer 1969 (with respect to forms with $d$ - in Old Osmanli): instead of being based on a general analysis of graphic systems, they are simply drawn from the historical dictionary (TS), i. e. reflect individual spellings.

Doerfer's second example of an "Iranism with voicing” is 'bag': Turkish dağar, Gagauz daar, Azeri dajar (Turkmen tajar-č̀tk 'camel's foam alveole' - a Kipchakism), Tuvinian taar 
$(<d h-$, or from Mong.); PTk *dagar, with attestation in Common Turkic (Hakas taar; in documents with MK tajar 'bag for grains etc.'; the most widespread meanings are 'big bag', 'big stoneware vessel', and 'chopping block for cattle', see ESTYa 1980: 120-122). The word was borrowed into Persian as taǵar (where it developed such meanings as 'bag /as a measure/' and 'food supply') and into Mong. as tajar 'bag'. The form tagara 'stoneware bowl' and similar forms, attested in Turkic languages since the $13^{\text {th }} \mathrm{c}$. (Tafsir), as Doerfer had justly noted (in Doerfer TMN II 512-519), is a Persian diminuitive that was re-borrowed into some Turkic languages. The Turkic word has an Altaic etymology (<PAlt *tagu; cf. PMo *toru-gan 'caldron', PTM: Evenki taja 'birch-bark basket'); PTk * $d$ - regularly becomes voiced $<$ PAlt ${ }^{*} t$ by assimilation with the word-medial voiced stop (see Dybo 2005: 53).

Again, in TMN: II, 512-519, Doerfer supposes (under question) that this word may have been borrowed from Turkic into Persian, although at the same time he assumes that the word is not Turkic in origin, but comes from an unknown language (based on a rather flimsy argument that there is no such Turkic root as *ta or *tag, from which this word could have been derived). All the forms listed there from "andere iran. Dialecte", including Yagnobi, Pashto, and Shugni, are obvious loanwords from Persian, but no Middle Persian form is attested, and Doerfer does not even try to provide an Iranian etymology for the Persian word. Shouldn't even a convinced follower of Doerfer's approach, given the presence of a rather elaborate etymology in TMN, remain skeptical towards a contradictory marginal remark in Doerfer 1971, with no arguments provided in its favor?

To these two examples of "voicing in Persianisms" one more example is added in the article Doerfer 1969: Turkish denk 'equal', ultimately a Sinitism = Chinese 等, contemp. děng, Mid-

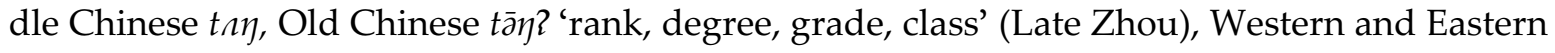
Han, Early Post-Han Chinese tẳ 'rank, degree; class, sort; order; row, category, group; company; similar; such as; a grammar word following lists; equal; identical; to compare' (Karlgren 1923: $0961 \mathrm{i}$ ). However, it is easy to show that in Persian this is a relatively recent Turkism. The situation is as follows: the attested forms in Persian (according to Doerfer's examples) are täng 'horse-load, bag (of sugar)'3 and däng 'half-load (for horse)' (Fazl-i-Ali 1979), 'equilibrium, balancing' (rarely) Rub., as well as dängadäng 'equal' (lit. 'däng against däng'). In Oghuz languages the forms are: Old Osmanlı däng 'correct weight' (P: III, 1660), deng 'half', teng 'one from a pair' (15th c., TS: II, 1062), Turkish denk 'equal, similar, pair; equilibrium; counterbal-

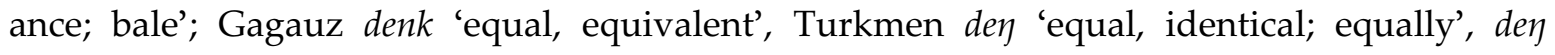
agramli 'equal by weight', Khorezm-Oghuz day 'equal' (Abdullaev 1961 I 36) ${ }^{4}$. The meaning 'counterbalance, half bale' is derived from the meanings 'equal weight, counterbalance on scales' (< 'equal'), attested already in Old Uigur (TT VIII; U II; from Old Uigur borrowed into Written Mongolian, MMo tey 'equal, straight, scales, counterbalance, bale' MA 346; Kow. 1691). It is evident that Oghuz forms demonstrate all the intermediate stages of semantic derivation, whereas Persian forms show only the final state (the expression dängadäng 'equal' is

${ }^{3}$ Persian täng 'girth', borrowed into some Iranian and Turkic languages, contrary to Doerfer, does not belong here; it is derived from the verbal root *tan- 'to pull, tie, weave' or *tang- / * $\theta a n g$ - 'to pull, weigh', see Horn $1893: 89$.

${ }_{4}^{4}$ Azeri tän 'even, equal', as correctly supposed by Doerfer, is borrowed from Chagatai. Azeri dial. (Dmanisi) taๆ 'is equal', listed in ESTYa under the word in question - most probably, a Kipchakism, borrowed from Kumuk

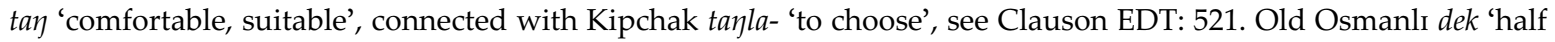
bale' $\left(13^{\text {th }}-14^{\text {th }}\right.$ c.), tek 'one from a pair' (14th c.), Turkmen tek 'one from a pair', dial. dek 'equal; half bale' (DS: IV, 1406) et al. also do not belong here, contrary to Doerfer, who supposes a "dialectal phonetic" development teng $>$ teg, upon which Karluk teg > tek and then this Karluk form was borrowed into all Turkic languages: in addition to the construction being extremely cumbersome, such a development as PTk* $-\eta>$ Karluk $-k$ is downright impossible. 
clearly secondary relative to the meaning 'counterbalance'). Therefore, it makes more sense to suppose that Oghuz forms reflect the Common Turkic situation; that initial voicing reflects Old Chinese non-aspirated articulation; and that Modern Persian has in some cases borrowed forms with initial voicing from Oghuz languages, and in other cases voiceless forms from Kipchak or Karluk languages. Even if Modern Persian has borrowed the word with the meaning 'equilibrium, counterbalance' from Late Ancient Uighur (but if so, where does the Persian initial voicing come from?), eastern Oghuz forms (Turkmen, Khorezm) with initial voicing and with the meaning 'equal' cannot be Persianisms and should be traced back to Common Turkic. It is possible that Mod. Uigur dey 'equilibrium' is borrowed from Mod. Persian (Menges 1955).

New research on Proto-Turkic voiceless/voiced consonants (see, for instance, Dybo 2005) has revealed a number of regular phonetic innovations within the Turkic family that have only confirmed the original assumptions of V. M. Illich-Svitych, who was looking for patterns of phonetic correspondences here, rather than occasional irregular changes. (Of course, this does not mean that we should underestimate Doerfer's research as an enormous contribution to the historical phonetics of Turkic languages.)

Overall, the fact that Robbeets rejects certain innovations in the reconstruction of ProtoTurkic does little to increase the methodological rigour of her own reconstruction; and even from a purely theoretical standpoint, it is understandable that the introduction of additional phonological distinctions to the reconstructed system often allows for a more efficient finegraining of suggested etymologies.

On p. 77, Robbeets writes that "the reconstruction of PTk * $n$ '- in initial position is still controversial". But nobody ever tried to reconstruct any initial sonorant consonants for PTk, it was even a problem for the Altaic comparison. The assumption that Hung. nyár 'summer' is a borrowing from Turkic *jār̆ 'spring; summer' is in itself beset with problems. ${ }^{5}$ We cannot make

${ }^{5}$ See Dybo 2007: 166. If we consider Hung. nyár (nyar-at) 'summer' a loanword dating to the Proto-Ugric period, we would have to suppose an extremely archaic form for the Turkic source (PTk *jäř 'spring; summer'). Since the word begins with $n y-$, in order to explain it we must reconstruct such a situation in Proto-Turkic (or in early Bulgar) where the nasal quality of the Proto-Altaic consonant that normally developed into PT * $j$ - was preserved. This situation should be earlier than, for example, the one reflected in borrowings into Proto-Samoyed - cf. PSam *jemńa- 'mend' < PTk *jama- 'knit up' < PAlt *nĕmè (EDAL). Apparently, this last argument decreases the credibility of the supposed borrowing, since (at least, according to contemporary opinion), the Proto-Ugric homeland was definitely to the west of the Samoyed ancestral home; consequently, the Turks, while advancing to the west, would only have encountered the Ugric people after the Samoyeds.

As to the etymology itself, we have the following difficulties here: (a) if it is a borrowing from Proto-Turkic into early Hungarian, the alternating length in Hungarian is hard to explain: Proto-Turkic long $\bar{a}$ in early loanwords is reflected as a non-alternating long vowel (see Räsänen 1937, Dybo 2010); (b) the original as well as the Bulgar meaning of the Turkic word is most probably 'spring' rather than 'summer'; (c) although, contrary to MNyTESz, for phonetic reasons the Hungarian word cannot be traced back to Proto-Uralic * $n E r V$ 'Rute, junger Sproß' (UEW: 331; the phonetically correct Hungarian parallel to this root is nyír, pl. nyírek 'Birke, betula; dial. junger Schößling; (OHung) Birkenwald'), it is not isolated, since we can alternately compare it with PSam *nårå 'Schneekruste; Frühling' (Nganasan nóru 'Schneekruste', noru 'spring', derivative noruo 'spring'; Enets nár̆a, nára 'Schneekruste', nara 'spring', derivative nareo 'das spätere Frühjahr'; Tundra Nenets rapa 'spring before ice drift, the time of ice crust', нарэй 'spring before ice drift; spring (adj.)'; Forest Nenets nārro a; Karagas nára 'spring' Janhunen 1977: 98; Helimski 1997: 722; contrary to Janhunen, Mator narha 'new' hardly belongs here, but rather to PSam *narp3 'new', Helimski 1997: 724). For Hungarian and PSam we can reconstruct a Proto-Uralic form *nare (ebase, judging by alternating length in Hungarian). In the light of all this evidence, it appears that a relationship exists between Uralic, Turkic and general Altaic forms. The Turkic form is traced back to PAlt *niáár [à] 'young; spring, summer': PMo *nirai, PTM *nar-gu-, MKor njarí-m, PJap *nátù (Ramstedt EAS I 111; Vladimirtsov 1929: 
any strong presumptions about PTk phonology based on one or two cases of dubious loanwords.

Regarding the issue of "rotacism / zetacism" in Proto-Turkic, Robbeets, while discussing the development of $z$, s from clusters, draws attention to Street's research (Street 1980) without mentioning the works by E. Helimski (1986a, 1986b) or my own paper (Dybo 1995 a), where some possible alternative cluster developments are suggested.

Finally, in her presentation of the reconstruction of Proto-Turkic vocalism, Robbeets mentions that the opposition of closed and open $e$ is not directly reflected in any Turkic languages. This is not quite true, since in Azeri and in Turkmen the opposition between open and closed syllables with primary long vowels directly reflects this Proto-Turkic opposition (see the presentation of evidence in Dybo 2007, and still earlier in SIGTYa 2002).

The next part of the monograph largely concerns sifting through comparative lexical material in order to select convincing evidence in favor of Japanese-Altaic kinship. No other thesis is being proven: the existence of the Altaic family as such is not placed under doubt by the author. In other words, Robbeets' aims, on the basis of EDAL, to select those comparisons that are hard to deny on the surface level, to check if they conform to a system of phonetic correspondences, to verify if they are numerous enough to rule out accidental similarity, and to analyze the feasibility of interpreting the Japanese part of the data as borrowings from a certain Altaic language.

First of all, Robbeets studies those cases where a Japanese cognate has an internal etymology that contradicts the Altaic comparison. Here it should be noted that the absolute priority of internal etymology over external is hardly found among the basic postulates of comparative linguistics. Cf., for example, the amateur etymology of Russian якорь 'anchor' as a haplology from $я \kappa о-\kappa о p b$ 'like a root' (in reality, the word is borrowed from Greek) - looking quite plausible on the surface, but definitely not true. One should take into account that in restricted etymological systems (e. g. in the case of language isolates) researchers often attempt to stretch the limits of internal etymology until the explanation is no longer satisfactory or even realistic. Thus, for Proto-Japanese *apa-mano 'food' (> AJP op(w)omono, Martin JLTT: 509), its internal analysis as 'big thing' is clearly a folk etymology: cf. the same root in the verbal derivative OJ $o p(w) o-k$ - 'to eat greedily'. In EDAL, the term "folk etymology" for such cases was used euphemistically - implying lack of serious phonetic or semantic evidence in proposals published earlier by researchers.

Regarding those cases where Robbeets suggests internal etymologization through morphological segmentation, one should also remember that, on strictly formal grounds, we could even detach the deverbal affix -ing in Eng. thing, Germ. Ding etc., although it is actually part of the stem (*penaz *penxaz sb.n.: Goth peihs 'occasion, time', ON ping 'assembly, thing', OE pin 'thing, meeting', OFris thing 'assembly; legal case; thing', OS thing id., OHG ding id., Orel 420). One should be particularly cautious when proposing such etymologies for compound words where their individual parts do not imply any regularity (such as MJ fitume 'tip of a hoof', where tume is explained as 'hoof', while $p i$ is given a very dubious explanation). The argument where the author proposes the existence of an early $i$ ' 5 ' based on comparison of itutu ' 5 ' and iso '50', ipo '100' seems unconvincing when viewed against the background of numerous examples of contracted compounds in Japanese. Subsequently, in the section on "Arbitrarily in-

145-146; Poppe VGAS: 38, 81; Martin 1966: 243; OSNYa II: 84; S. Starostin 1991: 74; SIGTYa 2000: 73-74) should best be investigated under the angle of an ancient genetic connection (Nostratic).

${ }^{6}$ Apparently, some attempts to find etymologies for Indo-European kinship terms are of the same nature; cf. *paté(r), gen. *patr-és, -ós “zu pō(i)- schützen?” (Pok. 829), etc. 
serted morpheme boundaries" one finds many cases whose analysis directly contradicts the logic of the section on "Undetected morpheme boundaries".

Nonetheless, it should be acknowledged that in many cases, challenges to EDAL etymologies are based on quite serious grounds.

In section 6.2 ("Morphology") the author lists several hypotheses on the origin of a number of Japanese grammatical formants, mostly explaining them through grammaticalization of lexical nouns; this section is arguably one of the most useful in the entire book.

Concerning "Nursery words and Sound Symbolism" (section 7), I would like to note once more that, in general, words suspected of sound-symbolic properties can be expected to slightly deviate from strict phonetic correspondences, but it hardly makes sense to dismiss out of hand otherwise phonetically and semantically satisfactory cases on the grounds that, bypassing standard etymologization, they can be explained within the general framework of such phenomena. Especially in a language with such a limited phonological inventory and such harsh restrictions on syllabic structure as Japanese, considering how vague are the criteria to define sound symbolism, it may be possible to treat almost any word as "soundsymbolic".

In Chapter 8, the author filters out cases that can be allegedly explained as borrowings into Japanese from other sources. Here we can only note that unequivocal borrowings may only be postulated for languages whose history is very well understood; for this reason, most of the explanations that suggest ancient borrowing from Ainu seem invariably less convincing than the alternate hypotheses of Altaic origin for such words - for example, the hypothesis about iruka 'dolphin' being borrowed from Ainu rika 'whale' is hardly more plausible, semantically and phonetically, than the suggested Altaic etymology. Borrowing from an unknown language (incidentally, such borrowings are quite often supposed in Turcology), as in the case of Japanese kuma and Kor. kwom, is a speculation that hardly deserves attention, unless there is significant internal evidence for this, such as a serious violation of phonotactic rules within a particular morpheme. And some of the hypotheses just leave a weird impression - e. g., the attempt to explain Jap. mara 'penis' by means of Bdh. Skt. ma:ra 'evil'. Yet on the whole, once again, criticism of particular EDAL etymologies is often useful and should be definitely paid attention in order to improve etymological analysis.

In chapter 10, Robbeets is checking if the established phonetic correspondences survive sifting and are still valid when restricted to the remaining material. Here it should be noted that it may have been preferable to rely on sources outside of EDAL to analyze phonetic issues - in the case of language groups with well-developed etymological traditions, the corresponding parts of EDAL entries should rather be viewed as condensed references to internal etymological dictionaries. In general, one can sense insufficient command of data on continental Altaic language groups on the part of the author. Thus, on p. 288 she contests the EDAL reconstruction of PTk *(j)ēn-čik 'shin' and modifies it to *inčik, based primarily on such forms as Turkish incik and Turkmen $i n z ̌ i k$. However, first of all, if there really is a reflex that contradicts the reconstruction of initial ${ }^{*} j$, it would not be the Oghuz forms (transition ${ }^{*} j$ - $>i$ - is fairly common in Oghuz languages), but rather Yakut inniäx (Pek. 1941; initial *j- in Yakut is expected to yield s-). Second, such reconstruction does not explain such Turkic forms as Middle Turkic jinžik (IM), Siberian Tatar jinžik (Tumasheva 1961), Shor enžik, Chalkan enčik, Bashkort jensek. As shown in Dybo 2007: 55-57 (and, earlier, in SIGTYa 2002: 40-42), in such cases we can reconstruct a descending diphthong (Ptk *ẹjn-čik), and such a Turkic protoform agrees with the Altaic reconstruction of the word * pèjné.

An interesting methodological innovation, introduced by Robbeets in this chapter, is matrix analysis of the correspondences. Despite its usefulness, however, the analysis contains cer- 
tain inaccuracies. Thus, matrix 1 analyzes the comparisons that should support nonrandomness of the correlation PJap ${ }^{*} p$ - : PKor ${ }^{*} p$ - : PTM ${ }^{*} p-:$ PMo ${ }^{*} h-\left({ }^{*} p\right.$ - according to Robbeets) : PTk ${ }^{*} b$-. At the same time, as I have already mentioned earlier, the author simplifies the PAlt reconstruction - but in this case, rather than rolling it back to the traditional version based on the "Ramstedt-Pelliot law" (PJ ${ }^{*} p-$ : PKor ${ }^{*} p$ - : PTM * $p$-: PMo ${ }^{*} h-\left({ }^{*} p\right.$ - according to Robbeets) : PTk ${ }^{*} 0$ - (Khalaj $h$-, as supposed by Doerfer)), she selects as the only correct one the innovative correspondence series of Illich-Svitych, where Turkic ${ }^{*} b$ - corresponds to voiceless consonants in the other groups (for these cases, the EDAL model proposes to reconstruct nonaspirated ${ }^{*} p$-). As for the cases that conform to the traditional row of correspondences, Robbeets simply removes the Turkic forms with 0 - as irregular (they are given in square brackets).

However, statistics seems to go against this decision. In matrix 1.1, there are 9 stems with Turk. $b$ - (and at least one of them was placed there by mistake: Turkic bir, PM *bueri, Jap *pito should have been listed in matrix 1.2.), and 15 stems with Turk. 0-/*y- (cases with dipthong), plus 3 more in the list of "irregular" cases in matrix 1.3. This gives us 8 "regular" cases against 18 "irregular" ones (!), and after all the manipulations, we are still basically left with 2 rows of correspondences: (a) PJ ${ }^{*} p$ - : PKor ${ }^{*} p$ - : PTM ${ }^{*} p$ - : PMo ${ }^{*} h-\left({ }^{*} p\right.$ - according to Robbeets) : PTk ${ }^{*} 0-$ and (b) PJ ${ }^{*} p-$ : PKor ${ }^{*} p-:$ PTM ${ }^{*} p-:$ PMo ${ }^{*} p-:$ PTk ${ }^{*} b-$. (The third row remains trivial: PJ ${ }^{*} p-$ : PKor ${ }^{*} p-:$ PTM ${ }^{*} b-:$ PMo ${ }^{*} b-:$ PTk $\left.{ }^{*} b-\right)$.

The same applies to the matrix that lists correspondences for dental consonants. We can detect that the correlation "PJ ${ }^{*} t-:$ PKor ${ }^{*} c^{-}:$PTM ${ }^{*} \check{c}^{-}:$PMo ${ }^{*}{ }^{*}-$ : PTk ${ }^{*} \check{c}^{-}$", including a cognate in Turkic, was recorded 8 times (2.3) and is considered regular. But the correspondence "PJ ${ }^{*} t$ : PKor ${ }^{*} t-:$ PTM *d- : PMo *d- : PTk* $d-\left({ }^{*} t-\right.$, according to Robbeets)", including a Turkic cognate, was attested 5 times (2.2), and in all these cases the Turkic cognate is placed in brackets, i.e. declared phonetically irregular. The correlation "PMo ${ }^{*} d-$ : PTk ${ }^{*} d-$ " is recorded another 5 times in (2.4), where its correlates in other branches are PTM ${ }^{*} z^{-}$, PKor ${ }^{*} c^{-}$, PJap ${ }^{*} t$-, and is declared regular, going back to PAlt *z- (pp. 297-300). At the same time, on p. 321-322 we see such matrices as "PJ ${ }^{*} y-:$ PKor ${ }^{*} c^{-}:$PTM ${ }^{*} z^{-}:$PMo ${ }^{*} z_{-}:$PTk ${ }^{*} j_{-}$" (also said to reflect PAlt ${ }^{*} z^{-}$) and "PJ * $y$ - : PKor * ${ }^{*}-:$ PTM ${ }^{*} d-:$ PMo ${ }^{*} d-:$ PTk ${ }^{*} j$ ", said to reflect PAlt ${ }^{*} d-$. On the latter group of examples, the author comments: "It can be remarked that a number of entries have pTk ${ }^{*} t$ as the Turkic reflex, but anticipating what follows the Turkic candidates do not stand the phonological test due to their problematic medial consonants and vowels". However, these candidates ("terpe-, "tört, " tāj-, *taš < ${ }^{*} t a l C$, ${ }^{*} t e \check{s}<{ }^{*} t e l C$, listed on pp. 321-322) generally demonstrate the same vocalic and consonantal composition as their Mongolian and Tungusic cognates (which have not been ruled out by the author), and if we add up the examples of "PTM * $d-$ : PMo *d- : PTk *d-" from matrix 2.2, the overall number becomes so impressive that it is hard to get rid of the feeling that the author discards a large number of perfectly valid etymologies simply because they do not fit into her "reductionist" theory, not properly founded upon the standard historical-comparative method.

Similar problems arise with the assumption, on p. 311, of the secondary character of PTM * $x$ - (even though the conditions of such a development remain unknown), where one of the arguments is the observation that word-medial * $x$ - is strangely absent in the PTM system. Actually, serious arguments in favor of the reconstruction of this phoneme in word-medial as well as word-initial position were already proposed in Dybo 1990 (with the publication of SSTMYa, the amount of available data on TM languages grew considerably compared to earlier work by Benzing, which explains a large number of innovations in the reconstruction of PTM that were accepted in EDAL). The other argument against the reconstruction of the "guttural triad" for PTM and PAlt is purely structural, based on alleged parallelism with the system of binary oppositions for other occlusive consonants. However, since the potential third 
series for labials, dentals, and fricatives was previously ruled out with serious violation of basic comparative-historical methodology, the argument is hardly acceptable.

The brief overview of the history of reconstruction of PAlt ${ }^{*} n-$ (p. 315) has no mention of Dybo 1995b, where the correspondence "PJ * $m$ - : PTM *n- : PMo *̌̌-", reflecting PAlt *n-, accepted in EDAL, was described in detail. On the other hand, the reconstruction of clusters as a possible origin for CTk ${ }^{*}$ s and ${ }^{*} z$ (pp. 330-332) seems to be promising and requires further consideration.

Overall, the phonetic table reconstructed in the monograph is seriously abridged compared to the version of EDAL. Although Robbeets mentions that the table only pertains to etymologies that include Japanese material and is not necessarily exhaustive for Altaic as a whole, in truth, the main reason for reducing the number of the reconstructed phonemes is the assumption of a series of unconditioned consonantal splits, with no explanations provided. This certainly does not improve upon the regularity of the model proposed in EDAL, and for that reason, the model of Robbeets cannot be considered as an advance on that model.

The last part of the monograph is given over to analysis of those etymologies from the core vocabulary that were selected as reliable. In the author's opinion, they constitute sufficient evidence to prove the Altaic affiliation of Japanese, and, in general, I agree with Robbeets' analysis. However, I do have certain objections to some odd methodological theses, proposed on p. 413 in the author's analysis of morphological parallels:

(1) In agglutinative languages the morphemes are mainly suffixes or unbound postpositions. They are in a peripheral position, a position where phonological erosion is expected

- but let us note in passing that there are plenty of language families with agglutinative prefixation as well, e. g. Abkhaz-Adyghe or Central Saharan;

(2) This is also true for a large number of Indo-European suffixes, like e. g. the proto-Germanic -iz plural that completely eroded in final position. However, the Germanic plural left a trace in the root due to the inflectional feature of Indo-European. Agglutinative word formation, on the contrary, tends to exact segmentation of root and morpheme. In Japanese, Korean and Altaic we do not expect inflectional fusion like the English mouse - mice in which a lost plural morpheme -iz can be traced in the phonology of the root.

In reality, however, no typological characteristic that is "immanent" to the language, be it flectivity or agglutinativity, can with complete predictability influence (or not influence) the phonetic processes in that language. Thus, the phenomenon of fusion is well attested for most Turkic and Tungus-Manchu languages. Moreover, such a phenomenon as "Uighur umlaut" is well known: in Modern Uighur, vowels of the stem change under the influence of vowels in subsequent syllables. For some words this phenomenon helps to determine which vowel $\left({ }^{*} U\right.$ or ${ }^{*}$ ) was present in the second syllable in Proto-Turkic (in most other languages, the difference has been erased because of labial vowel harmony): cf. Uig. beliq 'fish' < *balik, but Uig. yoruq 'light' < yaruk. In the same language, the degree of aperture in vowels of the non-first syllable depends on whether the syllable is open or closed, resulting in inflectional alternations (yaš-lar 'young person-Pl' - yaš-lir-i 'young person-Pl-3Prs'). If, over the course of subsequent changes in the language system, final narrow vowels get lost (and such events are known in the history of various Altaic languages), the forms would differ only by the alternating variants of the final vowel. Such phenomena are to be easily expected in the history of Altaic languages, which makes a precise reconstruction of Proto-Altaic vocalism an especially hard task. 
All said, despite various deficiencies of the author's approach described in this section, there can be no doubt that over the course of this research, conducted already a decade ago, Martine Robbeets has emerged as a serious, ambitious, and independent researcher, initiating the extremely important task of revising and thoroughly evaluating the new Altaic reconstruction (as presented in EDAL) that no other researcher or reviewer had really set for him/herself before that (or, for that matter, ever since).

The second monograph by Robbeets, published last year (2015: Diachrony of verb morphology: Japanese and the Transeurasian languages), is primarily focused upon the possibilities of reconstructing elements of Proto-Altaic morphology, mainly the verbal system. The author's choice was most likely influenced by recent research, which indicates that borrowing of verbal lexicon and verbal morphology is quite rare (cf. Loanword Typology Project, especially Wohlgemuth 2009). Because of this primary emphasis on grammatical topics, the work is saturated with information on the general typology of grammar and grammaticalization, and the author demonstrates close familiarity with practically all the main publications in this area.

In the introduction, Robbeets lists the main factors that have motivated her to attempt a proof of Altaic relationship from this angle. On the whole, the presentation gives a fairly reasonable impression; for some reason, however, the fact that EDAL actually did contain a substantial number of satisfactory grammatical parallels between various branches of Altaic is not mentioned (for that matter, nor do the other critics of EDAL usually pay any attention to this section of the dictionary). It is an entirely different matter that these parallels do not show much paradigmaticity, due to the fact that Altaic morphology is positional rather than paradigmatic. As for the attempt to discard the term "Altaic languages" altogether (and substitute it with the newlycoined "Transeurasian"), it is somewhat amusing, but is probably due to the irrational antipathy that some researchers experience in relation to this term, more than any other factors.

In general, we agree with the presentation of the chronology of Altaic divergence and the main features of different Altaic languages; however, a few remarks should be made:

(a) there is no record of Bulgar presence in Kazakhstan;

(b) concerning the literature on Xiongnu, there is no mention of Dybo 2007, which contained certain arguments in favor of the current reconstruction of Proto-Turkic;

(c) the idea, proposed by Doerfer, that the Khalaj branch had split from Common Turkic before Yakut remains unfounded. The phonetic properties on which Doerfer bases his classificatory argumentation are not shared innovations, but rather preserved archaisms. These are $h$ $<$ PAlt * $p$-; preservation of primary vowel length (where long and short vowels differ according to Oghuz model, but do not show Oghuz voicing); and preservation of ${ }^{*}-\delta$-. Final ${ }^{*} g$ in polysyllabic words was not lost. Khalaj morphology in general resembles Oghuz; verbal affixes of the first series preserve the archaic 1Pers.Pl. -UK. There is one peculiarity of Khalaj nominal declension which brings it closer to Chuvash - preservation of pronominal declension that, without yielding to analogical influence, has maintained the postvocalic genitive affix ${ }^{*} \eta>y$; although this feature could be considered archaic, in reality it is rather a secondary haplologic development, cf. a similar situation with the Genitive 2Pers. possessive form * ${ }^{*} \eta-U \eta$ $>-y$ along with the presence of the postvocalic genitive variety $-y n$. Thus, with respect to nominal inflection, Khalaj is closer to Oghuz languages, although only through preservation of archaic properties: the language did not undergo the innovations that covered Southern Siberia, Karluk and Kipchak groups (see Doerfer 1988: 79); 
(d) Eastern Old Turkic as an attested written language form is quite evidently NOT the ancestor of all attested Turkic languages with the exception of Chuvash and Khalaj. Specifically, it contains some innovations shared with some languages of the Northeastern group of Turkic (e. g. 1Pl -myz in finite verbal forms, etc.);

(e) The Northeastern group clearly does NOT constitute a genealogical branch. YakutDolgan and Tuva-Tofa are different branches and presumably split from CT at the same time as Oghuz. The splitting of the Oghuz branch is not related to the spread of the Mongol empire, having taken place much earlier. As was shown in many works of the Moscow school (mentioned above), the "voicing" of initial ${ }^{*} k$, *t is not an innovation, but an archaism; if the author does not accept this, she should explicitly dispute it. The actual common innovations of Oghuz are: the restructuring of the opposition $\ddot{a} \sim e$; the so-called Oghuz voicing of medial ${ }^{*}-k_{-},{ }^{*}-t-,{ }^{*}-p-$ after primarily long vowels; and the development of consonantal vocalic declension types;

(f) there is no substantial Bashkir presence in Uzbekistan and Kazakhstan, nor is there any substantial presence of Kazakh in Asia Minor;

(g) on Mongolic languages: it is not true that all contemporary Mongolic languages can be traced to the language spoken by Genghis Khan (p. 12). The Southern Mongolic languages of the Kukunor group (Mongghuer, Dunxiang, Baoan) presumably split from Proto-Mongolic much earlier, around the 5th century (this may have been related to the migration of the Xianbi clan Muyung into the region of Gansu in 313 A.D. (see Bichurin 1833: 844; cf. glottochronological data $-85-88 \%$ common matches on the 110 -item wordlist, as per Gruntov, Mazo 2015);

(h) the following passage, with reference to Nugteren 2011 (p. 14), is probably mistaken: "Whereas word-medial palatal breaking is still in progress in Mongolian proper, it has been completed in peripheral languages, for instance... a front vowel has been preserved in ... Kalmuck nüdn 'eye', whereas it resulted in a back vowel in ... Mongghuer nudu". However, palatal breaking has no relation to this, see Nugteren 2011: 36-37: "Common Mongolic vowel harmony involved two classes of vowels. The distinction between the two may have been an opposition between front and back vowels or may have been based on tongue root position. The QG languages do not provide additional evidence to resolve this matter". The surface back quality of Gansu $u(<* \ddot{u})$-vowels is almost identical with those of Khalkha. "In Monguor vowel harmony has broken down both in stems and in suffixation. The front rounded vowels * $\ddot{o}$ and ${ }^{*} \ddot{u}$ merged with their back counterparts ${ }^{*} o$ and ${ }^{*} u$. Nevertheless, the former harmonic constraints are clearly visible in many existing primary and derived stems... In Baoan and Dungxiang there are also only two rounded vowels left, but as Kangiia preserves four, generally corresponding to the four rounded vowels of CM";

(i) Tungusic: the term "Tungus-Manchu" remains preferable, since, as it has been shown in a number of works (Sunik 1962: 16-17; Vasilevich 1960; Avrorin 1957: 473; Avrorin 1959: 34), based on phonetic, morphological, and lexical arguments, the split of the Manchu branch was the first one to take place within the family, and it would be logical to reserve the term "Tungusic" for all the languages that remained. Should it be stressed that nothing is known about the linguistic affiliation of Sushen? Also, Kili, or the Kur-Urmian dialect of Nanai, by no means belongs to the Southern group - it is actually Northern Tungusic, close to Negidal;

(j) On Japonic and Korean, p. 20: how is the fact that Korean and Japanese families at some point coexisted on the Korean peninsula documented? Do we bring the Koguryo language as a representation of Japonic into discussion? And how should we interpret the statement: "their coexistence was discontinued when Japonic relocated to the Japanese Islands in the first millenium B.C.?" This suggests that their coexistence was somehow documented before the first millenium B.C., but in what sources? 
Additionally, it seems that the Farming/Language dispersal hypothesis (to which the author refers) contradicts historically attested facts. In reality, all cases of historically documented migrations and language spread have been due to the dispersal of nomadic stockraising peoples.

On pp. 45-88 we find an account of the main methodological principles of comparativehistorical research adopted by the author. We can agree with almost all of its points - this is a sound methodological chapter, providing basic information on morphological reconstruction as it is usually described in introductory courses (some of them are cited by the author). In particular, the following approach to internal reconstruction is introduced (pp. 47-48):

In internal reconstruction, alternations within a single synchronic stage of a language are "undone" as it were, and an earlier state is reconstructed. In this process, it must be ensured that a plausible developmental pathway can be traced from the earlier reconstructed form and function to the attested ones. In Middle Korean, for instance, there is a causative-passive marker that has numerous allophones MK $-A c$ ?-, $-G i-,-h i-,-i-$, $-y-$, and also has various functions: it either derives causatives from transitive and intransitive verbs or passives from transitive verbs. Combining phonological knowledge about velar lenition with insights into the general typology of the development from causatives into passives, allows us to undo the changes and reconstruct an original causative marker of the shape $\mathrm{pK}{ }^{*}-k i$ - (cf. Section 6.7.2).

Some minor comments are, however, necessary.

P. 48: "Theoretically, it follows that morphological reconstruction should always be preceded by phonological reconstruction. This is especially true for the Transeurasian languages, which are agglutinative and thus tend to share fewer idiosyncrasies useful for the establishment of fusional families like Indo-European. Shared irregularities such as the suppletive ego / me pronominal stems can demonstrate the correspondence between morpheme shapes without reference to regular sound correspondences". However, (1) pronominal stems are irregular in Altaic languages (cf. ol $\sim a n$ - in Turkic, bi na- in Mongolic); (2) the congruence of Lat. ego, Skt. aham and Slav. $a z b$ still can be shown only by means of the regular correspondences.

P. 55: "A genetic relationship can be demonstrated on the basis of regular correspondences in form and function. It should be kept in mind, however, that identifying correspondences does not require reconstruction. The reconstruction of Proto-Transeurasian morphemes is a by-product, rather than the primary goal, of the comparative method. As Harrison (2003: 225) puts it: "One can use the comparative method to draw genetic conclusions without reconstructing a thing." Nevertheless, the present work will propose concrete reconstructions for ancestral morphemes because they make the posited set of changes between the daughter languages and the ancestral language more visible and because they serve as the basic units of the overall ancestral morphological system".

I would not agree with the last point. To demonstrate genetic relationship, it is necessary to do more than simply show regular correspondences: it is also very important to show that it is possible to reconstruct a specific fragment of the protolanguage and to formulate historically realistic transition rules between the protolanguage and its descendant languages.

P. 58: "Some of these forms have even led to the reconstruction of a causative-reflexive in proto-Nostratic *t'V- by Kaiser and Shevoroshkin (1988: 313)." - The reconstruction of this morpheme was done by V.M. Illich-Svitych (OSNYa 1971: 13); Kaiser and Shevoroshkin gave an account of it for English readers.

P. 59: “... the probability that a certain correspondence in verb morphology is due to coincidence will be lower than that for a similar correspondence within the lexicon, because the body of elements open to comparison is much smaller" - this argument is quite dubious, 
since any assessment of the probability of chance coincidences should be carried out on joint lists of grammatical and lexical morphemes. Also, we must not ignore that decreasing the size of the sample automatically decreases the size of the confidence interval for it, meaning that the overall statistical reliability of the results is lower in the case of a smaller inventory of elements.

P. 61: "Metaphorically, the term 'copy' is obviously more correct than the term 'borrowing' because the model language does not give anything up, and the copying language does not give a borrowed item back. The main point, however, is that a copy is never identical with the model". Metaphoric notions of losing a "borrowing" by the donor language are resolved by the fact that we speak of information units, which do not get lost by the donor during transfer (cf. a similar situation when we still use the term 'borrowing': "Talent borrows, genius steals"). Additionally, the term "copy" does not seem to account for the very typical fact that, while at the time of borrowing the borrowed unit looks maximally close to the source unit, it then gradually adjusts to the constraints of the new language; cf. the difference between "adapted" / "non-adapted" borrowing (should the term "copy" be applied only to the latter?).

P. 62: "Their description of copiability as a relative tendency suggests that bound verb morphemes belong to the most stable parts of linguistic substance and provide fairly reliable evidence to demonstrate common ancestorship. Even though I believe that no single part of language structure is conclusive by itself, my decision to limit the scope of this book to bound verb morphology is based on this assumption". As nice as it looks, there are also known cases like Copper Island Aleut, where what we observe is precisely the borrowing of morphemes from bound verb morphology! (However, not the complete bound verb morphology system).

P. 64: "An indication of morphological borrowing is the restriction of shared morphemes to shared roots. This criterion is valid for derivational as well as for inflectional morphology. The borrowing of derivational morphology is a gradual process: first, the morphemes are borrowed along with lexical items; later, they become extracted and productive on other foreign bases and finally, on native bases. Matras (2009: 209) distinguishes between the term "forward diffusion" for the former case and "backwards diffusion" for the latter. The denominal verbalizers -ize and -ify, for instance, entered English in the 12th century through borrowings of Old French verbs ending in -iser and -efier /-ifier (e. g. baptize, stupefy, sanctify). From the 16th century onwards new verbs were derived, first, from Latinate (e. g. equalize, objectify), then from other foreign bases such as Greek (e. g. chondrify 'turn into cartilage (Greek chondros)') and, finally, from some native bases (e.g. womanize, ladify), but even in contemporary English -ize and -ify combine more frequently with foreign than with native bases (Marchand 1960, 238240, 255-259; Gottfurcht 2007: 84-85)".

This reasoning is by all means fair, but, theoretically, I could easily imagine some fervent anti-Indo-Europeanist who might try to debunk one of the most transparent proofs of IndoEuropean genetic relationship - common inheritance of two conjugation types, thematic and athematic, with partial preservation of lexical distribution - in the following manner: we can suppose that affixes of athematic conjugation were borrowed into Ancient Greek from, for example, an ancestor of Sanskrit (in its oldest state, still with the distinction of $e, o, a$, which later converged to $a$ in Indo-Iranian languages), first, for specific verbal roots ( ${ }^{*} e s m i>$ eimi 'I am' etc.), after which they spread to some proper Greek verbs (ollumi 'I kill', etc.). In such cases, it is really only our general experience, suggesting that such verbs as 'to be' and 'to eat' are not easily borrowed, that prevents us from setting up this scenario as at least equiprobable with the scenario of genetic inheritance.

P. 64: "Similarly, Wutun (Sinitic) has borrowed from Bao'an (Mongolic) the interrogative marker -mu, e. g. Wutun qe-lio-mu [eat-PFV-INTER] 'have (you) eaten?' (Janhunen 2012c: 25). The 
Wutun interrogative contains the Bao' an finite narrative marker $-m$ - and the interrogative $-u$, e. g. Bao'an ode-m-u [go-FIN-INTER] 'do (you) go?'. However, Wutun reinterpreted the morpheme without taking into account the tense-aspect marking”.

Actually, it might be more efficient to explain this particle as a borrowing from Bao'an - $m b u$, a combination of an affirmative word (focus particle) and an interrogative particle, borrowed into Wutun as a whole. Cf. Baо'an mа јуджі ідәрсанг мбу? "Aren't you tired from the journey?”, “нэ мәнэ мәсго мбу? “Are these my clothes?” (Todaeva 1964: 106).

P. 68: "The repeated marking of an inflectional category that has already been expressed is an indication of code-copying". Multiple marking of categories is a frequent phenomenon in agglutinative languages, especially in Siberia; in verbal forms it is traced to synthesized constructions with auxiliary verbs. In general, grammatical categories in agglutinative languages are very different from those in inflectional languages: they are not obligatory, nor do they always have a unique expression within a certain wordform. An example is cited: "For example, the verb forms kimumisti 'we are sleeping' and kimasti 'you (PL) are sleeping' in other Greek dialects correspond to the Silli forms kimumisti-niz and kimasti-niz, in which -iniz is copied from Turkish as a general marker of plurality without regard to person. We can thus say that the forms are double-marked for plurality". But cf. an indigenous Khakas form: Пaлbıxman иирзер nар-ар-быс-тар 'We will go fishing in the evening' (nap-ap-быc-map 'go-FUT-1.PL-PL), generated in a similar manner. Therefore, the criterion is not very reliable.

P. 69: "The semantic mismatch between "infinitive" and "verbalizer", occuring in this example (French traiter 'to treat' < Latin tracta:re) is a counter argument against inheritance".

This is also not a very good criterion. Such a semantic shift is, undoubtedly, due to the fact that Latin conjugation in -are includes a large number of denominal verbs, and it is a productive type for the formation of denominal verbs; therefore -are, even in Latin, functions as a verbalizer. Here (as in the following example with Yakut and Tungus) we can say that in borrowings the functions of the marker can sometimes be narrowed; but narrowing of a marker's functions can also occur in the course of historic development (cf. the development of the -lparticiple in Russian - from marking past tense in both primary and secondary predications, it shifted to exclusively primary predications).

P. 71: "Copper Island Aleut, Michif, Gurindji Kriol and Ma'a can be regarded as 'mixed' languages because different parts of grammar and lexicon come from different languages, to such an extent that it is impossible to assign them unequivocally to a single genealogical ancestor. The question arises whether in these cases 'mixed' refers to the nature of the languages having double ancestry or to the perception of the linguist, who may no longer be able to clearly distinguish the inherited from the copied subsystems. In my view, these "mixed" languages may represent instances of code-copying taken to an extreme".

It can hardly be doubted that at least for both Copper Island Aleut and Michif we can easily determine the genetic ancestor. In Copper Island Aleut it is clearly seen that verbal morphology is borrowed from Russian rather than Russian inherited. Only the most productive paradigmatic class of Russian conjugation is used, neglecting the base joining rules and with complete loss of lexical distribution. Two forms are borrowed for pronouns (Nom., Acc.) due to their relative infrequency in Aleut, since the corresponding meanings are usually expressed within the verbal wordform. In Michif, on the contrary, truly complex Cree verbal morphology is preserved, while French nominal morphology is so structurally simple that its borrowing can be easily explained.

P. 73: The example of "the contact-induced grammaticalization of the verb 'to make, do' to a causative auxiliary" is not very convincing, since such grammaticalization is typologically frequent (cf. French, Azerbaijani). 
As to the other criteria for borrowing (2.4.2.1 - productivity restricted to shared roots; 2.4.2.2 - unilateral morphological complexity; 2.4.2.3 - mismatch of morpheme boundaries; 2.4.2.6 - phonological mismatch; 2.4.2.7 - distribution limited to contact zones), these are well-described and quite convincing.

P. 74: "2.4.3 Indications of genealogical retention $\rightarrow$ 2.4.3.1 Globally shared grammaticalization": it would seem that "globally shared grammaticalization" cannot be taken as a criterion of inheritance, if it all amounts to a common morpheme which was grammaticalized after a typologically frequent model. In such cases it can hardly matter if this morpheme was commonly shared through inheritance or through contact.

P. 75: "The globally shared grammaticalization should be spread over more than two (proto-) languages." Everything that was said above on the low probability of the same morpheme being borrowed into a number of related languages is correct; however, if the grammaticalization pattern is sufficiently frequent (e. g. "go" or "want" for 'FUT', "do" for 'CAUS' etc.), then we can only speak of such probabilities for borrowing lexemes, rather than morphemes. On the other hand, a contradictory example may be found in the privative affix -sI/Uz, borrowed from Azeri into Budukh (Talibov 2007: 109), Kryz (Authier 2009: 70), and some other North Caucasian languages in Azerbaijan.

P. 76: Concerning criterion 2.4.3.3 ("Shared cumulation"), I must stress that any statements on the etymology of inflectional morphemes in languages for which there are no general comparative grammars or etymological dictionaries (e.g. the languages of Australia) must, by definition, be regarded as highly unreliable. Among such cases is the situation with case copying in Arnhem land, and the same holds for the alleged borrowing of denominals from Ritharnu to Ngandi: if the morpheme - $t$ - does not have the same meaning in Ngandi as it has in Ritharnu, it could simply represent a different affix, phonetically similar through sheer coincidence. This is a general flaw in contemporary typology of areal contact - as if the process of borrowing is not in itself an object of comparative linguistics and does not need to be subjected to strict etymological analysis, so that it becomes sufficient to merely state that " $\mathrm{A}$ is borrowed from B" without presenting actual historical evidence for this statement.

On the other hand, shared cumulation is not an absolute criterion for relatedness either. We know some cases of borrowing of cumulative affixes, e. g. Copper Island Aleut shows copying of Russian portmanteau person-number flexions in verbs (at the same time, Russian nominal flexions are not copied with the same degree of cumulativity). The example of borrowing from Yakut to Evenki, cited earlier by the author (pp. 67-68: "copying of the Yakut presumptive-assertive paradigm as presumptive in Uchur Evenki and as assertive in Lamunkhin Even. The copied suffix strings require specific accommodation with the marker $-r$ - in Evenki and with the connective glide $-j$ - in Even, which is not needed for the attachment of native suffixes") refers to cumulative borrowing, without morphemic analysis. And insertion of $-r$ - and $-j$ - does not mark borrowings it is typical of verbal stems that are incorporated into composite words (see Boldyrev 2007: 639).

Another disputable statement is: "When the semantic correspondence... concerns a meaning that is demonstrably secondary to one of the participating morphemes, we are probably dealing with a copy". What if this is merely a semantic change? Let us suppose that Genitive often develops from Ablative. In Sanskrit, the flexion -ad conveys the semantic roles of Ablative and Instrumental; its cognate in archaic Latin is similar. Let us further make an etymologically reasonable supposition that in Slavic its cognate conveys the meaning of Genitive. Since this is a secondary meaning in relation to Ablative, should we consider the Slavic morpheme a borrowing?

As for the first part of the cited observation ("when the semantic correspondence is so divergent that it cannot be explained by referring to cross-linguistically attested pathways of grammaticalization..., we are probably dealing with a copy"), here I would rather assume 
that, if the semantic development cannot be explained by a regular pattern of grammatical change, it is not even a borrowing - rather just a spontaneous coincidence.

Table 7, with the verbal paradigm of Copper Island Aleut, has some misprints: the root of the Russian verb "to speak" should be spelled govor- when transliterated and gavar- when transcribed. The example itself is not particularly successful: allomorphism in the paradigm of Russian verbs is reduced in Russian mutual common language when the flexion is unstressed [-ǐ̌, -it, -im, -ita, -'ut], so in this case it is not "copying” that caused this reduction.

P. 81: Section 2.5.2, "One cannot demonstrate unrelatedness", seems very well written and detailed. Only one important point should be added here: there is a very good way to prove unrelatedness of a certain language to a certain language group - that is, to prove its relatedness to another language group, i. e. to show that it belongs to a node on a totally different genealogic tree. No sooner do we have reliable proof of, say, common ancestry between Chukchee-Kamchatkan and Tungus-Manchu, Finno-Ugric and Mongolian, Austronesian and Japanese-Ryukyuan, Sino-Tibetan (or Hmong-Mien) and Turkic, etc., the issue of the Altaic family will be automatically taken off the agenda. Incidentally, none of the anti-Altaicists have so far succeeded in anything of the kind.

In general, the author's conclusions on the importance/necessity of morphological evidence do not raise any serious objections. It might only be added that the outstanding conclusiveness of Indo-European morphological parallels is also due to the uniform distribution of verbal paradigmatic types among groups of lexical cognates in different IE languages (when many verbs can be reconstructed for the protolanguage as specifically belonging to the athematic verbal class, etc.). Such a situation cannot obviously be expected of agglutinating languages where absence of lexically distributed paradigmatic classes is one of the main features, and, consequently, it is unreasonable to demand that comparative Altaic morphology should comply to the exact same requirements as comparative IE morphology.

The section on "Verb roots" (pp. 89-173) opens with a discussion of a particularly interesting problem. It is well-known that Altaic languages behave differently in respect to the coding of attributive words: Japanese and Korean code them as predicative (within the grammatical class of verbs), but continental languages treat them as term-words (belonging to the grammatical class of nouns). Consequently, the author sees herself obliged to establish the original coding, one that could be projected onto the Proto-Altaic stage.

In dealing with the issue of the formal definition of parts of speech, I cannot fully accept the position of Robbeets from the point of view of the contemporary state of theoretical linguistics and typology (although her assessment of the problem of syncretistic verbal-nominal stems is correct - namely, that the number of such stems in Altaic languages is vastly exaggerated by certain authors). The assertion that there are no languages without the distinction of "nouns", i. e. mainly term-words, and "verbs", i. e. mainly predicative words, should not be as simple as that: a strict, perfectly defined border often cannot be drawn between these categories, since different languages employ different sets of criteria to draw it, and in some cases it cannot be precisely defined as a certain feature that may be prescribed for lexemes in a vocabulary. It may be difficult to define such lexical classes (outside of purely semantic criteria) in a dictionary of isolating or analytical (such as, e. g., Polynesian) languages. Cf. a particularly complex case for the situation in Ancient Chinese (S. Starostin 1994).

In the place of certain terms I would have preferred more traditional ones, for example, attributives instead of property words and stative verbs instead of verbal adjectives.

P. 91: "Syntactically, they [adjectives] ... can enter comparative constructions. Morphologically, adjectives make use of specific derivation patterns, such as intensifying and deintensi- 
fying elements or partial emphatic reduplication". It should, however, be remembered that only qualitative attributives take part in comparative constructions and intensifying reduplications.

Some inaccuracies may be observed in the analysis of various coding types of certain attributives. Cf., on p. 98: "Note that some of these deverbal adnominalizers have denominal counterparts with the same form. Compare, for instance, WMo. -KAi in WMo. butara- 'fall to pieces' $\rightarrow$ butarqai 'dismembered' vs. WMo. qongqor 'hole' > qongqorqai 'uneven'. The observation that verbal and nominal bases can be turned into a nominally coded property word using one and the same morphological means, suggests that the concept "adjective" was originally perceived as a single category, distinct from nouns and verbs". However, butara- can also be analyzed as a denominal (deadverbial) verb with the suffix $-a$, and butarqai can be regarded as derived from the original name (adverb) butar 'in pieces'. Unfortunately, existing descriptions of derivational morphology in Mongolian languages often confuse denominal and deverbal models (not to mention additional semantic confusion because of imprecise English translations).

On p. 99, we have the following paragraph on Mongolian attributives: "Switched encoding. Middle Mongolian and Written Mongolian retain traces of switching, whereby the same property word can have both nominal and verbal encoding, e. g. Mmo bulqa 'hostile; hostility' and MMo. bulqa- 'to be hostile', WMo. boyus 'pregnant (of animals); fetus' and WMo. borus- 'to be(come) pregnant', WMo. qarsi 'contrary, opposed; obstacle' and WMo. qarsi- 'to be contrary, to be opposed' (Kara 1997: 158, 160), WMo. tasi 'slanting' (in tasi zam 'slanting, uphill road') and Wmo. tasi- 'to deviate, slant, slope, incline (intr.)"'. It deserves to be mentioned that, out of four examples, for three there can be no doubt that the original coding was nominal, since they are all Turkisms, based on borrowed nouns (boguz 'pregnant, in calf', qarši 'opposite, contrary', and taši 'mountain pass').

Some remarks on the analysis of the Turkic situation (3.2.5): the fact that many attributive words are derivationally deverbal does not in any way indicate proximity to verbs - many words that function as syntactic arguments are also deverbal, but that does not lead us to claim that nouns were originally verbs. Likewise, many verbs are also derived from adjectives and nouns, so this cannot serve as an argument. Formerly, N. K. Dmitriev (Dmitriev 1962: 34) proposed to distinguish in Turkic languages a separate lexico-grammatical class of qualitative adjectives which, characteristically, can be substantivized not only as an object possessing a certain quality, but also as a name for the quality itself - cf. the remarkable property of Turkic participles which can function not only as attributives but also as Nomina actionis. It is true that qualitative nouns can be distinguished in Turkic languages - but the difference between these two classes is of a quantitative rather than a qualitative nature; separate analysis of isolated taken syntactic constructions and derivational pairs does not provide any strict criteria to distinguish them properly. To do that, it is necessary to apply distributive-statistical methods.

One can also feel the influence of English translations on the interpretation of Turkic deverbal adjectives - p. 100: "OTk. kïzil 'red' from OTk. kïz- 'be red" - hardly so; a more accurate translation would be 'to glow red'; "OTk bädük 'big, great; greatness' from OTk. bädü'be(come) big, great'” - again, a more accurate translation would be 'to grow', while the primary meaning of *bädük is 'high'. In fact, these verbs are not truly stative verbs: they show processual semantics and cannot be judged as evidence in favor of the primarily verbal character of Turkic attributives.

With respect to the remarks made above, we can make the following comment on section 3.2.6 ("Scenario for the development of Transeurasian adjective typology"). Prototypical adjectives in the world's languages are qualitative; the typology of qualitative adjectives in the languages that concern us here is by no means mixed, but rather nominal; in Turkic, Mongolian 
and Tungus-Manchu they are evident nouns. In Korean qualitative adjectives are verbs and in Japanese also, those Japanese attributives that look nominal are an unproductive class (as is shown also in corresponding sections of the book under review) and, therefore, most probably residual. By the way, judging by these residual phenomena, we should rather talk of splitadjective typology for Japanese. Thus, the statement that "Transeurasian languages, at least in their earlier stages, share mixed adjective typology" is probably true, but the behavior of these systems with respect to productivity indicates that their typology was gradually changing from nominal coding to verbal, and, therefore, continental typology reflects an earlier stage (the author proposes an inverse scenario).

A small remark on table 2 ("Etymologies relating Japanese verbal adjectives to adjectives in the Transeurasian languages"): Tk baya $(-k I)$ 'recently' is a denominal attribute name, pTk *baya is an adverbial-attributive noun (ESTYA 2, 30); Ud. baji 'early' $\leftarrow$ pTg *baji (not *badi!) is a noun, see SSTMYa 1: 64.

The cross-linguistic map on p. 105 (borrowed from the World Atlas of Language Structures, http://wals.info/chapter/118), is not very characteristic of the issue in question: it is a map of verbal / non-verbal encoding of predicative adjectives. Another map that provides data for a different syntactical position (Feature 60A: Genitives, Adjectives and Relative Clauses http://wals.info/feature/60A\#2/10.6/150.5), would probably be more useful, as it shows that non-verbal encoding (not as relative clauses) is inherent to many languages of the area.

This general section is then followed by an analysis of attributive and verbal root etymologies which the author traces back to the Proto-Altaic stage. As in Robbeets' previous monograph, they mostly represent polished versions of EDAL etymologies, for most of which derivational and semantic features are analyzed much more thoroughly than it was done in the source. The sound correspondences of EDAL are reduced to a smaller table that had already been set up and justified in Robbeets 2005.

A few specific remarks must be made. First, on the etymology of the aforementioned *baya 'early' - the author states: "The expected medial consonant reflex in the Old Turkic cognate is $-d-$, according to the sound correspondence PJ *-y-:: pK *-l-:: pTg *-d-:: pMo *-d-:: pTk * $d-$. Intervocalic $-d$ - in Old Turkic developed over a fricative $d$ in Kharakhanid to a glide $-y$ - in Middle Turkic and in some contemporary varieties, e. g. OTk adak > Kharakh. adaq > MTk ayaq 'foot'. In some cases, the lenition is already completed in Kharakhanid, e. g. OTk. adaš > Kharakh. adaš ayaš 'foot'. If the Turkic member pTk *baya- 'earlier, recent' belongs here, we must assume that the lenition was already completed in Old Turkic, as was the case for the initial pTk ${ }^{*} y-<{ }^{*} d-"$ (p. 111). This statement contains certain errors. First, there is no such pair as Kharakhanid adaš ayaš 'foot'; adaš means 'friend', rather than 'foot'. ' Second, such South Siberian reflexes as Khakas paja, Shor paja, Tuvinian bije, Tofa bije, clearly support PTk ${ }^{*}-j-\left({ }^{*}-d-\right.$ would have yielded Khakas, Shor $-z-$-, Tuvinian, Tofa $-d-$-). The comparison in EDAL consisted of potential cognates between Japanese, TM, and Turkic, with the reconstruction of PAlt ${ }^{*} j$; Robbeets also adds the Korean reflex pparu- 'to be quick, fast; early', MK polo- 'to be straight, fast, act quickly' vs. MK spolo- 'to be fast; be sharp, pointed', but it cannot be cognate to the Turkic forms.

P. 112: "Ma. sara- 'to become white', Ma. sari 'light', Evk. se:ru:- 'to sparkle, glitter, flash', Evk. se:ru:n, dial. še:ru:n 'rainbow' (cf. pTg *-n deverbal noun; Section 7.5.3), Evk. sereme 'yellow' (cf. pTg *-mA nominalizer; Section 7.4.3), Orok se:rro, siro 'rainbow', pTg *sia:ra- 'to be light, white’”. Evk. sereme means 'grey', not 'yellow', and it cannot be connected to Evk. se:ru:n

${ }^{7}$ Mahmud al-Kashgari mentions the form ayaq as a dialectal (Oghuz) variant of adaq 'foot', see Clauson EDT: 44. 
'rainbow' because of the difference between the vowels in the roots. 'Rainbow' is reconstructed as common Proto-Tungusic *siārü(n), accordingly derived from the verb *siār $\bar{u}$ - 'to sparkle, glitter, flash'. Since the vocalism does not correspond to that of the words in Manchu, the cited Manchu color terms probably do not have any equivalents in Proto-Tungusic, and may be considered Mongolisms. In Proto-Turkic *siārï-g a diphthong should be reconstructed, since the Chuvash reflex šur- 'to become white' indicates a narrow vowel of the second syllable rather than - $a-$ - generally speaking, the law of $i$-breaking before $a$ in Proto-Turkic has not been proven yet, but, on the contrary, there are certain reasons to reconstruct a system of diphthongs or diphthong-like combinations in Proto-Turkic, see SIGTYa 2006: 159, Dybo 2007: 4648. In Old Turkic there is no such form as šarïg 'yellow', see below.

P. 114: 'be high': PJ *taka- 'to be high'; $\mathrm{pK}$ *teki- 'to increase, make high'; pTg *deg- 'to go up'; pMo *dege- 'to be high'; pTk *yeg 'high part; better as'. This comparison is better than the one accepted in EDAL, at least as far as the "continental" language groups and Korean are concerned. The Japanese cognate is not very appropriate because of both vowels and consonants (we would expect *d-). It would seem better to restore Japanese *dò- 'good' as a correlate, since its semantics agrees well with both Korean and Turkic.

P. 117: pJ *koru- 'be hard, painful', $\mathrm{pK}{ }^{*} k w o l w u$ - 'be hard, painful'. Here I would have preserved the PTM cognate *xurge 'heavy' from EDAL, with a standard nominal suffix. The Turkic counterpart in EDAL, indeed, does not look very reliable, since it consists of two different entities: a) OT ${ }^{*} \mathrm{Kir}$, a noun functioning as an intensifying epithet to the words with the meaning 'enemy' - as a pejorative intensifier, the word hardly permits any reasonable hypotheses about its original meaning; b) Oghuz *Kir-an 'epidemic, destruction', deverbal noun = Kipch.-Oghuz *Kir-gin from the verb *Kir- 'to destroy, exterminate'.

Section 3.3 ("Verbs") begins with a discussion of phonetic correspondences between various Altaic languages. Not surprisingly, the author mainly repeats the system already exposed in Robbeets 2005; I only have a few additional points to make.

Concerning the argument on PAlt vowel harmony (pp. 125-126): the phonetic / articulatory basis for vowel harmony can shift easily. Vowel harmony can easily disappear and reemerge, and it can also undergo typological change under the influence of neighboring languages (cf. the situation in Chuvash, Uzbek, Modern Uighur - at least according to SIGTYa 2002). As to RTR-harmony, which is currently quite fashionable and is being ascribed to nearly any vocalic system that sounds unusual for the English or the Russian ear, see Aralova 2015, where it is shown quite convincingly that for Tungus-Manchu (and the same is also correct for quite a few other languages of the world), there has really been no reliable instrumental research on articulatory phonetics so far that could demonstrate that phonological or morphophonological vowel harmony in these languages truly relies on RTR; on the other hand, for some languages whose reliance on RTR has been convincingly demonstrated, researchers have observed the opposite phonetic consequences of what is usually assumed about TM. Therefore, it seems rather premature to state with confidence that PAlt had vowel harmony and, moreover, that it was based on RTR articulation.

As to the vocalic correspondences in EDAL, it is true that they have not been elaborated to perfection - at the very least, Proto-Turkic vocalic reconstruction has not been carried out rigorously in all comparisons; and for Proto-Tungusic, a slightly simplified reconstruction from S. Starostin 1991 was taken (at least for PTM, we currently prefer to reconstruct vowel harmony). However, EDAL took an approach that increased the explanatory power of the reconstruction, namely, assuming the possibility of the influence of the second vowel on the first vowel in bi- or polysyllabic stems. Robbeets completely omits this part - and, therefore, it is completely unclear (table 17), for instance, how MK kùt- 'to be hard' (kwut in Yale notation) 
can be traced to $\mathrm{pK}$ *kata-; even with the reference to table 16 , it is still noted that $\mathrm{MK} w u<\mathrm{PK}$ ${ }^{*} u$ (in EDAL this development is accounted for by setting up a labial vowel in the second syllable: PAlt $\left.{ }^{*} k^{\prime} e t^{\circ}{ }^{8}\right)$. On the other hand, the internal distribution of Japanese vocalic reflexes proposed by Robbeets (pp. 127, 130, 131) is original and deserves special attention.

Pp. 89-173 are given over to the analysis of verb etymologies. These largely represent refined versions of EDAL comparanda, usually without comments, and often with parts of previously included comparanda removed from the etymology for various reasons. In general, we can agree with many of the edits; a particularly important step forward compared to EDAL is the author's attempt to provide derivational analysis for the compared forms (the same attempt was also made in the section on adjectives). However, in the process some minor inaccuracies in the analysis of continental data still managed to creep in, cf. some examples:

Table 27: The Ancient Turkic runic form is given as šarïg 'yellow', however, śarïy (as in EDAL) would be more accurate. Earlier, it was implied (Mudrak 1988) that the postulation of the Proto-Turkic diphthong, primarily based on Chuvash palatalization, could also be supported by cases where in Orkhon runic inscriptions we see consonants, usually typical for words with front vocalism, in words with back vocalism (although the hypothesis remains questionable). In any case, it is the Chuvash form that should have been listed here - the testimony of Ancient Turkic is much weaker;

p. 136: (on *sïp-, *sïp-kar- 'to swallow') "The formant in Mtk sipqar- and Az. sïfqar- is probably the lexicalized causative pTk ${ }^{*}-g A r$. The lack of voice is explained by the fact that the opposition $/ \mathrm{k} /: / \mathrm{g} /$ is very weak after consonants in Old Turkic". Actually, the lack of voice is explained not by the weakness of the opposition, but by the synchronic rule for the selection of affixal allomorphs - one that still functions in modern languages, as well as in Old Turkic;

p. 149: nebse-yi- 'to be wide and long (of clothes)' (cf. also p. 109: muru-yi- 'to be bent'): -yiis not a deverbal affix (and not anti-causative either: an anti-causative verb is an intransitive verb that shows an event affecting its subject, while giving no semantic or syntactic indication of the cause of the event), but a denominal affix with the meaning of a stative verb, i. e. intransitive qualitative verb; it is used, in particular, for deriving pro-verbs from pronouns (te-yi- 'to do so', ka-yi- 'to do what?'). See Chuluu Ujiyediin 1998: 67-68, where it is stated that this affix forms verbs of regular meaning (implying neutral Aktionsart) from adverbs, with nebse-yi- as one of the examples). The same source quite plausibly explains the formation of deverbatives with -gar as derivatives from these verbs, with regular omission of the suffix. Thus, these derivatives do not confirm the verbal nature of the original stem.

In the note 18 on page 151 the author seems to misunderstand the development rules for PTM ${ }^{*} \ddot{O}$ and ${ }^{*} u$, the way they were conceived by Benzing. She provides the following table (“according to the correspondences in Benzing 1955"):

\begin{tabular}{c|c|c|c|c|c|c|c|c|c|c}
\hline PTg & Ma & Evk & Even & Sol & Neg & Oroch & Ud. & Olch. & Orok & Na \\
\hline${ }^{*} \ddot{\mathrm{o}}\left({ }^{*} \Lambda\right)$ & $\mathrm{u}$ & $\mathrm{u}$ & $\mathrm{o}$ & $\mathrm{u}$ & $\mathrm{u}$ & $\mathrm{o} / \mathrm{u}$ & $\mathrm{o}$ & $\mathrm{o} / \mathrm{u}$ & $\mathrm{o} / \mathrm{u}$ & $\mathrm{u}$ \\
\hline${ }^{*} \mathrm{u}$ & $\mathrm{u}$ & $\mathrm{u} /-\mathrm{i}^{9}$ & $\mathrm{u} / \ddot{\mathrm{i}}$ & $\mathrm{u} / \ddot{\mathrm{i}}$ & $\mathrm{u} / \ddot{\mathrm{i}}$ & $\mathrm{u}$ & $\mathrm{u}$ & $\mathrm{u}$ & $\mathrm{u}$ & $\mathrm{u}$ \\
\hline
\end{tabular}

${ }^{8}$ Although I would agree with Robbeets on the elimination of Manchu etu-xun 'strong, hard' from the comparison.

9 - $i$ appears here because of the second syllable of the trisyllabic form *aduli 'net', which Benzing himself did not reconstruct accurately enough. According to the materials, in his reconstruction it should have been *adüli; I would now prefer to reconstruct this form with a diphthong $\left({ }^{*}\right.$ adujli). 
Benzing himself does not provide a table of vowel correspondences, but on pp. 23-24 he discusses examples which, according to his opinion, should have either one or the other of these vowels in the protoform. If we draw a table for these examples (see also more accurate transcriptions for the modern languages in SSTMYa and other more recent sources), it will look as follows ("MF" means morphophonological frontness, "MB" means morphophonological backness):

\begin{tabular}{|c|c|c|c|c|c|c|c|c|c|c|}
\hline PTg & Ma. & Evk. & Even. & Sol. & Neg. & Oroch & Ud. & Olch. & Orok & $\mathrm{Na}$. \\
\hline${ }^{*} \ddot{O}\left({ }^{*} \Lambda\right)$ & $\mathrm{u}, \mathrm{e} / \mathrm{P}_{-}$ & $\begin{array}{l}\mathrm{u} \\
(+\mathrm{MF})\end{array}$ & $\begin{array}{l}\mathrm{e} / \mathrm{u} \\
(+\mathrm{MF})\end{array}$ & $\begin{array}{l}\mathrm{u} \\
(+\mathrm{MF})\end{array}$ & $\begin{array}{l}\Theta / \mathrm{u} \\
(+\mathrm{MF})\end{array}$ & $\begin{array}{l}\mathrm{u} \\
\left({ }^{*} \mathrm{CuCu}\right. \\
>\mathrm{CoCo})\end{array}$ & $\mathrm{o} / \mathrm{\Theta}$ & $\begin{array}{l}\mathrm{u} \\
\left({ }^{*} \mathrm{CuCu}\right. \\
>\mathrm{CoCo})\end{array}$ & $\begin{array}{l}\mathrm{u} \\
\left({ }^{*} \mathrm{CuCu}\right. \\
>\mathrm{CoCo})\end{array}$ & $\mathrm{u}$ \\
\hline$* \bar{O}$ & $\begin{array}{l}\text { uwe, } \\
\text { we/0_ }\end{array}$ & $\begin{array}{l}\overline{\mathrm{u}} \\
(+\mathrm{MF})\end{array}$ & $\begin{array}{l}\mathrm{\Theta} / \mathrm{u} \\
(+\mathrm{MF})\end{array}$ & $\begin{array}{l}\mathrm{u} \\
(+\mathrm{MF})\end{array}$ & $\begin{array}{l}\Theta / \mathrm{u} \\
(+\mathrm{MF})\end{array}$ & $\mathrm{u}$ & $\mathrm{o} / \mathrm{\Theta}$ & $\mathrm{u}$ & $\mathrm{u}$ & $\overline{\mathrm{u}}$ \\
\hline${ }^{*} \mathrm{u}$ & $\mathrm{u}$ & $\begin{array}{l}\mathrm{u} \\
(+\mathrm{MB})\end{array}$ & $\begin{array}{l}\mathrm{u} \\
(+\mathrm{MB})\end{array}$ & $\begin{array}{l}\mathrm{u} \\
(+\mathrm{MB})\end{array}$ & $\begin{array}{l}\mathrm{u} \\
(+\mathrm{MB})\end{array}$ & $\begin{array}{l}\mathrm{u} \\
\left({ }^{*} \mathrm{CuCu}\right. \\
>\mathrm{CoCo})\end{array}$ & $\mathrm{u}$ & $\begin{array}{l}\mathrm{u} \\
\left({ }^{*} \mathrm{CuCu}\right. \\
>\mathrm{CoCo})\end{array}$ & $\begin{array}{l}\mathrm{u} \\
\left({ }^{*} \mathrm{CuCu}\right. \\
>\mathrm{CoCo})\end{array}$ & $\mathrm{O}$ \\
\hline
\end{tabular}

Thus, the first syllable in Benzing's system for PTM *töru- 'to hold' is reconstructed correctly, but it could be reconstructed much more reliably from such forms as Evk. туринмукэн'to restrain smb. with smth.', where the vocalism clearly reveals the property of morphophonological frontness (-ken-, and not -kan-). As for the second syllable, I would rather reconstruct its PTM vocalism as ${ }^{*} i$ than ${ }^{*} u$ : labialization in Even is due to labial attraction, and in some other languages it may be due to the accommodation of the causative-passive suffix ${ }^{*}-b u-\rightarrow$ -wu- and similar (see SSTMYa 2: 330). (Additionally, I myself now conceive the PTM vocalism somewhat differently - see the system of correspondences in my article "Tungus-Manchu languages" in BRE 31, forthcoming in 2016).

The section on copulas (3.4, pp. 153-163) seems flawed inasmuch as a whole mix of different Turkic formants is traced back to the same existential verb ${ }^{*} \bar{a}$-. From a morphosyntactic perspective, this seems reasonable for the denominal verbalizer $-A-$, as well as for the formant - $A$ - in the durative participle $-A-g A n$, but hardly makes sense for the deverbal nominalizer (actually, a future participle) $-A r$ and the $-A$. In fact, even the denominal verbalizer $-A$ - is not a perfect candidate, since it forms both transitives and intransitives.

Justification of low probability of verb borrowing in Transeurasian languages because standard borrowing strategies do not coincide (pp. 168-169) does not seem very convincing to me, since borrowing strategy as a typological feature can vary broadly and evolve in the course of language history - who really knows which particular strategies were preferred by the ancestors of Japanese and Korean peoples in the 2nd millennium BC?

Without going into too much detail on the analysis of verbal markers (pp. 174-484), constituting the central part of the monograph, it may be said that, on the whole, it looks fairly convincing; however, it would be desirable to strengthen the paradigmatic approach with a more detailed study of the development of each marker in all the categories of every language group.

Negation in Altaic, in particular, is analyzed quite thoroughly. We definitely agree that (p. 207) "the indications of inheritance are stronger than those of diffusion". In addition to simple correspondences between "nasals", we have a rigorous vocalic correspondence and a well-established grammatical class. One remark: on p. 205 it is supposed that the reflex of the PAlt negative verb *an- in Old Turkic is anïg anïg ayïg 'evil, sin' as a deverbal noun in - $g$-; however, this scenario does not work, since the Turkic word should clearly be reconstructed with palatal ${ }^{*} n-$, which would contradict at least the Tungusic reflex ${ }^{*} n-$. 
"Verbalization and Actionality" (pp. 209-270): the title of this chapter is somewhat confusing, since, in addition to Aktionsarten, it also covers the subject of denominal verb derivation, and out of all the affixes that are discussed only one (PAlt * $g a$ - 'inhoative') carries the semantics of action development. The reference to Bybee 1985: 100 on p. 209: "the semelfactive in Russian kašljanut' 'to cough' and blesnut' 'to flash' is situated halfway between lexical and derivational expression because these stems do not occur without the element -nu-, which prevents us from identifying -nuas a suffix" is quite suspicious - actually, in these verbs the suffix - $n u$ - can be very easily separated from the root, cf. the respective forms without this suffix: kašljat', blestet' (with the phonetic development $\left.-n^{-}>-n-\right)$. Even if this is a minor remark, it goes a long way in showing how unsafe it can be to rely blindly upon typological data without the necessary precautions.

The analysis of verbal derivation affixes is mostly excellent; however, the chronological reasoning (pp. 225-226) which is used as an argument in favor of the archaic character of the affixes, looks a bit naïve. In particular, Robbeets refers to Bakker and Hekkig 2012, who, based upon the material of Spanish loanwords in Quechua, Guarani, and Otomi, have established the time period necessary for the borrowed derivational affixes to become productive as equal to 500 years. But why should we think that this time period is necessarily universal? Let us assume that the deverbal noun suffix -izirova-, borrowed from German, becomes productive in Russian some time around the 1920s, while the stream of German loanwords that brought this suffix begins about mid-1700s; this puts an upper limit of 170 years (probably even less, about 150 years) that was needed in order to make the German suffix -isier-(en) (borrowed from French) productive in Russian. If we accept 150 years as a possible term for becoming productive, the chronology, presented on p. 226, would change in the following manner: ther table below depicts chronological conflict in Vovin's borrowing scenario of the deverbal noun suffix *la.

\begin{tabular}{l|l|l}
\hline \multicolumn{1}{c|}{ Stage in borrowing process } & \multicolumn{1}{c}{ Example } & \multicolumn{1}{c}{ Estimated date } \\
\hline Proto-Turkic original & $\begin{array}{l}\text { OTk. boguz 'throat' } \rightarrow \text { boguzla- 'to } \\
\text { cut the throat (tr.)' }\end{array}$ & before 100 BC \\
\hline Mongolic borrows Turkic verbs & $\begin{array}{l}\text { No base } \rightarrow \text { MMo. bo'orla- 'to cut } \\
\text { the throat (tr.)' }\end{array}$ & after 100 BC \\
\hline productivity & $\begin{array}{l}\text { pMo *-lA-: WMo. cegeji(n) 'mem- } \\
\text { ory' } \rightarrow \text { cegejile- 'to memorize (tr.)' }\end{array}$ & $\begin{array}{l}\text { after 50 AD (instead of Robbeets' } \\
400 \text { AD) }\end{array}$ \\
\hline Tungusic borrows Mongolic verbs & $\begin{array}{l}\text { No base } \rightarrow \text { Ma. šejile- 'repeat by } \\
\text { heart' }\end{array}$ & $\begin{array}{l}\text { after 50 AD (instead of Robbeets' } \\
400 \text { AD) }\end{array}$ \\
\hline productivity & $\begin{array}{l}\text { gucule- 'to make friends'; Even tew } \\
\text { 'berry' } \rightarrow \text { tewle:- 'to gather berries'; } \\
\text { Ud. anda 'friend' } \rightarrow \text { andala- 'to } \\
\text { make friends'10 }\end{array}$ & $\begin{array}{l}\text { after 200 AD (instead of Robbeets' } \\
400 \text { AD) }\end{array}$ \\
\hline
\end{tabular}

It is much closer to the chronology of split that was proposed by the author (p. 225-226: "These estimated dates for productivity, summarized in Table 1, conflict with the real dates of productivity proto-Khitan-Mongolic and proto-Tungusic. Since Khitan preserves reflexes of *-lA-, the suffix can be traced back to the common ancestor of Khitan and Mongolic, i. e. before 180 AD. This argument is even stronger for Tungusic: as all contemporary Tungusic languages reflect *- $l A$ - it must have been productive in proto-Tungusic, i. e. at least before 220 AD”).

${ }^{10}$ Again, though, the Ud. example is inappropriate, since anda 'friend' was borrowed from Mongolic. 
It is also hard for me to agree with the assessment of the PTk reflexive - $\mathrm{Xn}$ as a reflex of the PAlt verbalizer *-na. The argument on p. 237 ("Although the majority of $-X n$ - derived verbs do not refer to a direct object, some verbs, such as OTk. basïn- 'to come under stress (intr.), impose restraint on oneself (intr.), oppress, repress (metaphorically) (tr.),' can become transitive when used in a metaphorical, benefactive sense. This semantic modification without impact on the valency of the verb can serve as an indication that we are dealing with an original actional suffix instead of a diathetical marker") does not look convincing, since this is the only typologically expectable behavior of reflexives and medials - cf. the situation in Latin and Ancient Greek; also Nedyalkov, Geniushene 1991: 251-272. Actually, we could limit this comparison to only a small number of Chuvash denominative verbs in $-n$, and this, taking into account the essential possibility of ambiguous verbal-nominal roots for Turkic languages, does not look too promising - most of such derived verbs in Chuvash are intransitive (cf. Levitskaya 1976: 166-167).

The conclusion on the drift of verbalizers from nouns via adjectives to verbs undoubtedly looks interesting, but we have to remark that it contradicts the author's own thesis on the primarily verbal nature of adjectives in Altaic languages.

Voice affixes are very expertly analyzed (pp. 271-328), in particular because the author had the opportunity to rely on mostly accurate solutions in earlier research literature on Altaic languages. (Technical remark: for some reason, the left running title has "spread" from this chapter over to chapter 7, "Nominalization and the development of finite temporal distinctions", pp. 330-449, which made navigation across the book more complicated).

Chapter 7 begins with a section on the typology of "finitization". I should say that, as a specialist in continental Altaic languages, I find most of its argumentation somewhat superfluous for diachronic research, since it is fairly obvious that almost all finite forms in TungusManchu, Mongolian, and Turkic languages are not distinguished (or, at least, have not been distinguished until very recent times) from the corresponding forms of secondary predications (deverbal nouns, participles, gerunds - all carrying the same TAM meaning), i. e. they can be viewed simply as nominal predicates. The only difficult moment is the origin of the Turkic preterite in $-d I$, which, among other things, demonstrates (as well as the conditional mood in $-s a-)$ a different system of personal endings that could possibly represent some archaic relics of a pre-Altaic state. For this form, however, Robbeets does not propose any Altaic parallels.

Again, the study of the etymologies of common Altaic deverbal nouns is conducted very accurately. Some problems remain as far as Mong. and Turk. reflexes of PAlt * $k a$ are concerned: as we mentioned earlier, Robbeets does not take into account the currently accepted distinction between PMo. ${ }^{*}-g$ - and ${ }^{*}-\gamma-\left(\text { or }{ }^{*}-2-\right)^{11}$. Likewise, it is difficult to distinguish between Turkic * $k$ - and ${ }^{*}-g$ - at morpheme boundaries; this can probably be done only with the help of indirect information (such as the existence of duplicate affixes with deleted $-g_{-}-$but then, how legitimate would it be to match them?). Voiced and voiceless gutturals outside the first syllable in simple stems in modern Turkic languages (upon which, as Robbeets notes on p. 413, transcriptions for Ancient Turkic forms are usually dependent) are mostly the results of secondary development of voiceless consonants - automatic intervocalic voicing in South Siberian languages; voicing when preceded by a sonorant after primary long vowel and in the position more than one syllable away from the beginning of the word in Oghuz lan-

${ }^{11}$ This opposition does not have a fully straightforward correlation with the dropping of the velar consonant in modern Mongolic languages. The conditions, nevertheless, are quite definite (e. g. ${ }^{*}-\gamma_{-}>-g$ - by dissimilation if the wordform contains another ${ }^{*}-\gamma$ - or has a glide-containing diphthong, according to the so-called Vladimirtsov's rule), ruling out possible accusations of irregularity on behalf of our anti-Altaicist colleagues. 
guages; lack of voicing after sonorant and primary short vowel of the first syllable in Oghuz languages (for even more details see the section on Oghuz morphonology in SIGTYa 2002: 96-103), etc. Voicing - but not dropping - of the initial guttural in affix after vocalic stem endings speaks in favor of reconstructing ${ }^{*}-k_{-}$, whereas dropping rather indicates ${ }^{*} g_{-}$, so here we would expect different consonants for different affixes, as we have it in Mongolian languages.

As for the inclusion of the conditional marker ${ }^{*}-s A r$ into the group of reflexes of the PAlt nominalizer ${ }^{*} s a$, this seems more dubious than the inclusion of the Chuvash future participle marker - $A s$, which corresponds to one of the common Turkic present tense markers, appearing after the negative marker: $(-m A-) s$ (along with $(-m A-) z,(m A-) r)$, see Levitskaya 1976: 85-87, Kormushin 1984: 29.

On the whole, the analysis gives a very favorable impression: in particular, the author succeeded in making some plausible conjectures about the combinatory potential of every reconstructed affix (p. 443). The same applies to the reconstruction of two Proto-Altaic gerund affixes $-{ }^{*}-i$ and ${ }^{*}-k u$, although, as far as accuracy of the reconstruction of the initial consonant in the second affix is concerned, see notes above on PAlt * ${ }^{*} a$.

In summary, the author succeeded in reconstructing, quite accurately and plausibly, the form and functionality of 19 verbal markers. Although all of these etymologies, wholly or in part, had already been published in previous literature on Altaic languages, Robbeets has managed to make a more precise selection of cognates, based on careful analysis of morpheme usage in separate languages and language groups, and in a number of cases successfully proposed new specific affinities between morphemes and realistic typological foundations for change in usage and semantics, postulated for certain etymologies. The author is correct in stating that the groups of reconstructed affixes form a kind of paradigmatic relationship. Of course, a more serious discussion on the reconstruction of paradigms will only be possible once we have reconstructed for a grammatical category the entire history of the development of grammatical affixes from Proto-Altaic to all of the individual languages, i. e. when we have shown how all of the systems reflecting it in descendent languages were formed. In some cases this seems possible, but should be relegated for future research. At the present time, complete success in this direction seems unlikely, considering that, overall, the morphology of Altaic languages is mostly non-paradigmatic.

We can fully agree with the author's explanation of qualitative and quantitative differences between Altaic and Indo-European reconstruction (section 9.4: "Why is the evidence not consistent with the Indo-European model?"). Indeed, it would be strange to expect from the Altaic reconstruction "clearcut inflectional paradigms in the core parts of nominal and verbal morphology" which are demanded, for instance, in Janhunen 2014: 3 (it should also be noted that Janhunen's conception of the degree of successful reconstruction for Proto-Indo-European paradigms is somewhat exaggerated). Nevertheless, we must acknowledge that a major step forward towards a better grounding of the morphological reconstruction of Proto-Altaic has been undertaken by Martine Robbeets in this book.

\section{References}

Abdullaev 1961 - Абдуллаев Ф.А. 1961. Ўзбек тихининг Хоразм шевалари [Yzbek tilining Khorazm shevalari]. Tashkent.

ARS 2006 - Азербайджанско-русский словарь [Azerbaydzhansko-russkiy slovar']. Vol. 1-4. Baku, 2006.

Authier 2009 - Authier, G. 2009. Grammaire kryz (langue caucasique d'Azerbaïdjan, dialecte d'Alik). Leuven/Paris: Peeters. 
Avrorin 1957 - Аврорин, В.А. 1957. Новые исследования по языкам народностей Севера [Novye issledovaniya po yazykam narodnostey Severa]. Изв. АН СССР, ОЛЯ 5(5): 469-477.

Avrorin 1959 - Аврорин, В.А. 1959. Граммматика нанайского языка [Grammmatika nanayskogo yazyka]. Vol. 1. Moscow/Leningrad.

Balanovsky et al 2011 - Balanovsky O. et al. 2011. Parallel evolution of genes and languages in the Caucasus region. Molecular Biology and Evolution 28(10): 2905-2920.

Bentley 2008 - Bentley, John. 2008. A linguistic history of the forgotten islands: a reconstruction of the proto-language of the Southern Ryukyus (Languages of Asia 7). Folkestone: Global Oriental.

Benzing 1955 - Benzing, Johannes. 1955. Die tungusischen Sprachen: Versuch einer vergleichenden Grammatik. Wiesbaden.

Bichurin 1833 - Бичурин, Иакинф. 1833. История Тибета и Кукунора [Istoriya Tibeta i Kukunora]. Saint-Petersburg.

Blažek 2005 - Blažek, Václav. 2005. Current progress in Altaic etymology. Folia Orientalia 52(1): 237-254.

Blažek 2007 - Blažek, Václav. 2007. [Rev. of]: Robbeets, Martine Irma: Is Japanese related to Korean, Tungusic, Mongolic and Turkic? In Folia Orientalia 42-43: 467-470.

Boldyrev 2007 - Болдырев, Б.В. 2007. Морфология эвенкийского языка [Morfologiya evenkiyskogo yazyka]. Novosibirsk: Nauka.

Borodovskiy 2001 - Бородовский, А. П. 2001. Археологические параллели поясной гарнитуры угросамодийских народов Приобья [средневековье]. Самодийцы: Материалы IV Сиб. симп. “Культ. наследие народов Зап. Сибири” (Тобольск, 10-12 дек. 2001 г.) [Arkheologicheskie paralleli poyasnoy garnitury ugrosamodiyskikh narodov Priob'ya [srednevekov'e]. Samodiycy: Materialy IV Sib. simp. “Kul't. nasledie narodov Zap. Sibiri" (Tobol'sk, 10-12 dek. 2001 g.)]. Tobolsk: 22-24.

BRE - Большая российская энцииклопедия [Bol'shaya rossiyskaya enciklopediya]. T. 1-35-. Moscow, 2004-.

Bybee 1985 - Bybee, Joan L. 1985. Morphology: a study of the relation between meaning and form (Typological Studies in Language 9). Amsterdam: Benjamins.

Clauson EDT - Clauson G. 1972. An etymological dictionary of Pre-Thirteenth-Century Turkish. Oxford.

Dmitriev 1962 - Дмитриев Н.К. 1962. Строй тюркских языков [Stroy tyurkskikh yazykov]. Moscow.

Doerfer MT - Doerfer G. 1985. Mongolo-Tungusica. Wiesbaden.

Doerfer TMN - Doerfer G. 1963, 1965, 1967, 1975. Türkische und mongolische Elemente im Neupersischen. Vols. 1-4. Wiesbaden.

Doerfer 1969 - Doerfer G. 1969. Ein altosmanisches Lautgezetz im Kurdischen. Wiener Zeitschrift für die Kunde des Morgenlandes 62: 250-263.

Doerfer 1971 - Doerfer G. 1971. Khalaj Materials. Bloomington.

Doerfer 1978 - Doerfer G. 1988. Zetacism/sigmatism plays no rôle! Central Asiatic Journal 32: 61-63.

Doerfer 1988 - Doerfer G. 1988. Grammatik des Chaladsch. Wiesbaden.

D-T - Doerfer G., Tezcan C. 1980. Wörterbuch des Chaladsch: Dialekt von Charrab. Budapest.

Dudkin 1995 - Дудкин Х. И. 1995. Аллаиховский говор эвенов Якутии [Allaikhovskiy govor evenov Yakutii]. SaintPetersburg,

Dybo 1990 - Dybo, Anna. 1990. Inlautnye guttural'nye v tunguso-man'chzhurskom i praaltajskom [Medial gutturals in Manchu-Tungusic and Altaic]. In Sravitelno-istoricheskoe yazykoznanie na sovremennom etape [Historical comparative linguistics on a contemporary level]. Moscow: Nauka: 51-53.

Dybo 1992 - Дьбо А.В. 1992. Семантическая реконструкция в алтайской этимологии. Диссертация на соискание ученой степени доктора филол. наук [Semanticheskaya rekonstrukciya v altayskoy etimologii. Dissertaciya na soiskanie uchenoy stepeni doktora filol. nauk]. Moscow: Institute of Linguistics RAS.

Dybo 1995a - Dybo A.V. 1995. Once more about the adjusting of the Nostratic theory with the results of the Turkic studies. Московский хингвистический журнал 1. Mоscow: RSUH: 280-288.

Dybo 1995b - Дьбо А.В. 1995. Судьба праалтайского *ń- по тунгусоманьчжурским и монгольским данным. Владимириевские чтения 3 [Sud'ba praaltayskogo *ń- po tungusoman'chzhurskim i mongol'skim dannym. In Vladimircevskie chteniya 3]. Moscow.

Dybо 1996 - Дььбо А.В. 1996. Семантическал реконструкция в алтайской этимологии. Соматические термины (плечевой пояс) [Semanticheskaya rekonstrukciya v altayskoy etimologii. Somaticheskie terminy (plechevoy poyas)]. Moscow.

Dybo 2004 - Дыбо А.В. 2004. К проблеме происхождения имитативных слов. Тюркская и смежная лексикология и лексикография. Сборник к 70-летию Кенесбая Мусаева [K probleme proiskhozhdeniya 
imitativnykh slov. Tyurkskaya i smezhnaya leksikologiya i leksikografiya. Sbornik k 70-letiyu Kenesbaya Musaeva]. Moscow: 68-76

Dybo 2005 - Дьбо А.В. 2005. Дентальные взрывные в пратюркском. Aспекты компаративистики 1 [Dental'nye vzryvnye v pratyurkskom. Aspekty komparativistiki 1]. Moscow: RSUH: 49-82.

Dybo 2007 - Дьбо А.В. 2007. Аингвистические контакты ранних тюрков. Аексический фонд. Пратюркский nepuod [Lingvisticheskie kontakty rannikh tyurkov. Leksicheskiy fond. Pratyurkskiy period]. Moscow: Vostochnaya literatura.

Dybo 2010 - Дьюбо А.В. 2010. Вокализм раннетюркских заимствований в венгерском [Vokalizm rannetyurkskikh zaimstvovaniy v vengerskom]. In Gedenkschrift für Eugen A. Helimski. Finnisch-Ugrische Mitteilungen 32/33.

Dybo, Starostin 2007 - Dybo, Anna V., George S. Starostin. 2008. In defense of the comparative method, or the end of the Vovin controversy. Aspects of Comparative Linguistics 3. Moscow: RSUH Publishers: 109-258.

EDAL - Starostin S.A., Dybo A.V., Mudrak O.A. 2003. An etymological dictionary of Altaic languages. Leiden.

ESIYа - Расторгуева В.С., Эдельман Д.И. 2000-2011-. Этимологический словарь иранских языков [Rastorgueva V.S., Edelman D.I. Etimologicheskiy slovar' iranskikh yazykov]. Vols. 1-4-. Moscow.

ESTYа 1980 - Севортян Э.В. 1980. Этимологический словарь тюркских языков. Общетюркские и межтюркские основы на Г, Д [Sevortyan E.V. 1980. Etimologicheskiy slovar' tyurkskikh yazykov. Obschetyurkskie i mezhtyurkskie osnovy na $G, D]$. Moscow.

ESWYа - Стеблин-Каменский И.М. 1999. Этимологический словарь ваханского языка [Steblin-Kamenskiy I.M. 1999. Etimologicheskiy slovar' vakhanskogo yazyka]. Saint-Petersburg.

Fazl-i-Ali 1979 - Fazl-i-Ali. 1979. A Dictionary of the Persian and English Languages. New Delhi.

Fedotov 1996 - Федотов М. Р. 1996. Этимологический словарь чувашского языка [Etimologicheskiy slovar' chuvashskogo yazyka]. Vols. 1-2. Cheboksary.

Georg 2003 - Georg, Stefan. 2003. Japanese, the Altaic theory and the limits of language classification. In Osada, Tosiki \& Alexander Vovin (eds.). Perspectives on the Origins of the Japanese Language. Kyoto: International Research Center for Japanese Studies: 429-448.

Georg 2004 - Georg, Stefan. 2004. Review of: Sergei Starostin, Anna Dybo, and Oleg Mudrak: Etymological Dictionary of the Altaic Languages (EDAL). Diachronica 21(2): 445-450.

Georg 2009 - Georg, Stefan. 2009. Review of: Martine Robbeets: Is Japanese Related to Korean, Tungusic, Mongolic, and Turkic? Bochumer Jahrbuch zur Ostasienforschung 33: 247-78.

Gruntov, Mazo 2015 - Грунтов И.А., Мазо О.М. 2015. Классификация монгольских языков по лексикостатистическим данным [Klassifikaciya mongol'skikh yazykov po leksikostatisticheskim dannym]. Journal of Language Relationship 13(3-4): 205-255.

Helimski 1986а - Хелимский Е.А. 1986. Решение дилемм пратюркской реконструкции и ностратика. Вопросы языкознания 5 [Reshenie dilemm pratyurkskoy rekonstrukcii i nostratika. Voprosy yazykoznaniya 5].

Helimski 1986b - Хелимский Е. А. 1986. Происхождение древнетюркского чередования r z и дилемма “ротацизма-зетацизма". Советская тюркология 2 [Proiskhozhdenie drevnetyurkskogo cheredovaniya r z i dilemma "rotacizma zetacizma". Sovetskaya tyurkologiya 2].

Helimski 1997 - Helimski E. 1997. Die Matorische Sprache. Szeged.

Horn 1893 - Horn P. 1893. Grundriss der neupersischen Etymologie. Strassburg.

IM - Battal Aptullah. 1934. Ibnü-Mühenna lûgati. Istanbul.

Janhunen 1977 - Janhunen J. 1977. Samojedischer Wortschatz. Gemeinsamojedishe Etymologien. Helsinki.

Janhunen 2003 - Janhunen, Juha (ed.). 2003. The Mongolic languages. London / New York: Routledge.

Janhunen 2014 - Janhunen, Juha. 2014. Ural-Altaic: The polygenetic origins of nominal morphology in the Transeurasian zone. In Robbeets, Martine \& Walter Bisang (eds.). Paradigm change: In the Transeurasian languages and beyond (Studies in Language Companion Series 161). Amsterdam: Benjamins: 311-333.

Johanson, Lars. 1998. The history of Turkic. In Lars Johanson \& Éva Á. Csató (eds.). The Turkic Languages. New York: Routledge: 81-125.

Kaiser, Shevoroshkin 1988 - Kaiser, Mark \& Vitaly Shevoroshkin. 1988. Nostratic. Annual Review of Anthropology 17: 309-329.

Kara 1997 - Kara, Gyorgy. 1997. Nomina-verba mongolica. Acta Orientalia Academiae Scientiarum Hungaricae 50: 155-162.

Kara, Gyorgy. 2007. Review of: Martine Robbeets, 2005, Is Japanese Related to Korean, Tungusic, Mongolic and Turkic? Anthropological Linguistics 49: 95 -98 
Karlgren 1923 - Karlgren B. 1923. Analytic dictionary of Chinese and Sino-Japanese. Paris.

Knüppel 2006 - Knüppel, Michael. 2006. Ein Beitrag zur Japanisch-Koreanisch-Altaischen Hypothese'. Wiener Zeitschrift für die Kunde des Morgenlandes 96: 353-64.

Knüppel 2013 - Knüppel, Michael. 2013. Stellungnahme zu V. Blažeks Besprechung eines Beitrags zum "MakroAltaischen". Studia Etymologica Cracoviensia 18: 161-166.

Kormushin 1984 - Kormushin, Igor Valentinovich. 1984. Sistemy vremen glagola $v$ altajskich jazykach [Verbal tense systems in the Altaic languages]. Moscow: Nauka.

Kow. - Kowalewski J.E. 1844-1849. Dictionnaire mongol-russe-français. Vols. 1-3. Kazan.

Kushniarevich. A. et al 2015 - Alena Kushniarevich, Olga Utevska et al. 2015. Genetic heritage of the Balto-Slavic speaking populations: a synthesis of autosomal, mitochondrial and Y-chromosomal data. PloS ONE 10.9.

Levitskaya 1976 - Левитская Л.С. 1976. Историческал морфология чувашского языка [Istoricheskaya morfologiya chuvashskogo yazyka]. Moscow.

МА - Поппе Н.Н. 1938. Монгольский словарь Муккадимат ал-адаб. Ч. 1-2. Трудь Ин-та востоковедения АН CCCP 14 [Poppe N.N. 1938. Mongol'skiy slovar' Mukkadimat al adab. Ch. 1-2. Trudy In-ta vostokovedeniya AN SSSR 14].

Martin 1966 - Martin S. E. 1966. Lexical Evidence Relating Korean to Japanese. Language 42(2).

Martin 1996 - Martin, Samuel Elmo. 1996. Consonant lenition in Korean and the Macro-Altaic question. Honolulu: University of Hawai'i Press.

Martin JLTT - Martin, Samuel Elmo. 1987. The Japanese Language Through Time. New Haven: Yale University Press.

Mayrhofer IA - Mayrhofer M. 1986-1996. Etymologisches Wörterbuch des Altindoarischen. Vols. 1-2. Heidelberg.

Menges 1955 - Menges K. 1955. Glossar zu den volkskundlichen Texten aus Ost-Turkestan. Meinz.

Miller 2004 - Miller, Roy A. 2004. Review of: Starostin et al. 2003 (EDAL). Ural-Altaische Jahrbücher, N.F. 18: 215225.

Miller 2007 - Miller, Roy A. 2007. Review of: Robbeets 2005. Ural-Altaische Jahrbücher, N.F. 21: 274-279.

Miyake 2003 - Miyake, Marc Hideo. 2003. Old Japanese. A phonetic reconstruction. London / New York: Routledge.

Mgst. IIFL - Morgenstierne G. 1938-1973. Indo-Iranian frontier languages. Vols. 1-4. Oslo.

Mgst. EVP 1927 - Morgenstierne G. 1927. An etymological vocabulary of Pashto. Oslo.

Mgst. EVP 2003 - Morgenstierne G. 2003. A new etymological vocabulary of Pashto. Wiesbaden.

Monier-Williams - Monier-Williams M. 1851. A dictionary English and Sanskrit. London.

Mudrak 1988 - Мудрак О.А. 1988. К вопросу о палатализации начальных согласных в чувашском языке. Исследования по чувашскому языку [K voprosu o palatalizacii nachal'nykh soglasnykh v chuvashskom yazyke. Issledovaniya po chuvashskomu yazyku]. Cheboksary.

Nedyalkov, Geniushene 1991 - Недялков В.П., Генюшене Э. 1991. Типология рефлексивных конструкций. Теория функциональной грамматики. Персональность. Залоговость [Tipologiya refleksivnykh konstrukciy. In Teoriya funkcional'noy grammatiki. Personal'nost'. Zalogovost']. Saint-Petersburg: Nauka: 241-276.

Nichols 1992 - Nichols, Johanna. 1992. Linguistic diversity in space and time. Chicago: University of Chicago Press.

Nichols 2014 - Nichols, Johanna. 2014. Derivational paradigms in diachrony and comparison. In Robbeets, Martine \& Walter Bisang (eds.). Paradigm change: In the Transeurasian languages and beyond (Studies in Language Companion Series 161). Amsterdam: Benjamins: 311-333.

Norman 2009 - Norman Jerry. 2009. A new look at Altaic. Journal of the American Oriental Society 129(1): 83-89.

Nugteren 2011 - Nugteren H. 2011. Mongolic phonology and Qinghai-Gansu languages. Utrecht.

Orel 2003 -Orel V. 2003. A handbook of Germanic etymology. Brill / Leiden / Boston.

OSNYа - Иллич-Свитыч B.M. 1971-1984. Опьт сравнения ностратических языков [Illich-Svitych V.M. 19711984. Opyt sravneniya nostraticheskikh yazykov]. Vols. 1-3. Moscow.

Pek. - Пекарский Э.К. 1959. Словарь якутского языка. Vols. 1-3. Moscow.

Poppe 1955 - Poppe, Nicholas. 1955. Introduction to Mongolian comparative studies. Helsinki: Suomalais-Ugrilainen Seura.

Poppe VGAS - Poppe N. 1960. Vergleichende Grammatik der altaischen Sprachen. Teil 1. Vergleichende Lautlehre. Wiesbaden.

Pok. - Pokorny J. 1959. Indogermanisches etymologisches Wörterbuch. Bern.

Ramstedt EAS - Ramstedt G.J. 1952-1957. Einführung in die altaische Sprachwissenschaft. Bd. 1: Lautlehre. Bd. 2: Formenlehre. Helsinki. 
Räsänen 1937 - Räsänen M. 1937. Über die langen Vokale der türkischen Lehnwörter im Hungarischen. FUF 24: 246-255.

Rastorgueva 1990 - Расторгуева В.С. 1990. Сравнительно-историческал грамматика западноиранских языков [Sravnitel'no-istoricheskaya grammatika zapadnoiranskikh yazykov]. Moscow.

Roberts, B.W., M. Vander Linden (eds.). 2011. Investigating archaeological cultures: material culture, variability, and transmission. New York: Springer.

Rub. - Рубинчик Ю.А. (ред.). 1970. Персидско-русский словарь [Rubinchik Yu.A. (red.). 1970. Persidsko-russkiy slovar']. Vols. 1-2. Moscow.

Sunik 1962 - Суник О.П. 1962. Глагол в тунгусо-маньчжурских языках [Glagol v tunguso-man'chzhurskikh yazykakh]. Moscow / Leningrad.

SIGTYа 2000 - Сравнительно-историческая грамиатика тюокских языков: Лексика [Sravnitel'no-istoricheskaya grammatika tyurkskikh yazykov: Leksika]. Moscow.

SIGTYа 2002 - Сравнительно-историческая грамлатика тюркских языков: Региональные реконструкици [Sталnitel'no-istoricheskaya grammatika tyurkskikh yazykov: Regional'nye rekonstrukcii]. Moscow.

SIGTYа 2006 - Сравнительно-историческая грамматика тюркских языков. Пратюокский язык-основа. Картина мира пратюрка [Sravnitel'no-istoricheskaya grammatika tyurkskikh yazykov. Pratyurkskiy yazyk-osnova. Kartina mira pratyurka]. Moscow.

SSTMYа - Сравнительный словарь тунгусо-маньчжурских языков [Sravnitel'nyy slovar' tunguso-man'chzhurskikh yazykov]. Vols. 1-2. Leningrad, 1975-1977.

Stachowski 1993 - Stachowski Marek. 1993. Dolganischer Wortschatz. Kraków.

Stachowski 2005 - Stachowski, Marek. 2005. Turkologische Anmerkungen zum altaischen etymologischen Wörterbuch. Studia Etymologica Cracoviensia 10: 227-246.

G. Starostin 2009 - Starostin, George. Review of: Lyle Campbell and William J. Poser, Language classification: history and method. Journal of Language Relationship 2: 158-174.

S. Starostin 1991 - Starostin, Sergej A. 1991. Altajskaja problema i proisxozdenie japonskogo jazyka [The Altaic problem and the origins of Japanese]. Moscow: Nauka.

S. Starostin 1994 - Старостин С.А. 1994. Заметки о древнекитайском языке. Знак: сборник статей по хингвистике, семиотике и поэтике [Zametki o drevnekitayskom yazyke. Znak: sbornik statey po lingvistike, semiotike $i$ poetike]. Moscow: 93-126.

Street 1980 - Street J. 1980. Proto-Altaic *-l(V)b- Turcic š. CAJ 24(3-4).

Svantesson 1985 - Svantesson J.-O. 1985. Vowel harmony shift in Mongolian. Lingua 67: 283-327.

Talibov 2007 - Талибов Б.Б. 2007. Будухский язык [Budukhskiy yazyk]. Moscow: Academia.

Todaeva 1964 - Тодаева Б.Х. 1964. Баоаньский язык [Baоan'skiy yazyk]. Moscow.

TS - XIII. yüzyıldan beri Türkiye Türkçesiyle yazılmış kitaplardan toplanan tanıklariyle tarama sözlüğ̈̈. 1-8. Ankara, 1963-1969.

Tsabolov KES - Цаболов Р.А. 2001-2007. Этимологический словарь курдского языка [Etimologicheskiy slovar' kurdskogo yazyka]. Vols. 1-2. Moscow.

Tsabolov OIF - Цаболов Р.А. 1976. Очерк исторической фонетики курдского языка [Ocherk istoricheskoy fonetiki kurdskogo yazyka]. Moscow.

TT VIII - Gabain, A. von. 1952. Türkische Turfan-Texte. 8: Texte im Brāhmīschrift. ADAW 7.

Tumasheva 1961 - Тумашева Д.Г. 1961. Көнбатыш Себер татарлары теле: Грамлатик очерк һәм сүзлек [Konbatysh Seber tatarlary tele: Grammatik ocherk ham syzlek]. Kazan.

Turner - Turner R.L. 1962-1964. A comparative dictionary of the Indo-Arian languages. London.

U - Müller F.W.K. 1908; 1910; 1922; 1931. Uigurica 1-4. APAW.

UEW - Redei K. 1986-1989. Uralisches etymologisches Wörterbuch. Budapest.

Vámbéry 1901 - Vámbéry H. 1901. Alt-osmanische Sprachstudien. Leiden.

Vasilevich 1960 - Василевич Г.М. 1960. К вопросу о классификации тунгусо-маньчжурских языков. Вопросы языкознания 2: 43-49 [K voprosu o klassifikacii tunguso-man'chzhurskikh yazykov. Voprosy yazykoznaniya 2: 43-49].

VEWT - Räsänen M. 1969. Versuch eines etymologisches Wörterbuchs der Türksprachen. Helsinki.

Vladimirtsov - Владимирцов Б.Я. 1929. Сравнительная грамматика монгольского письменного языка и халхаского наречия: Введение и фонетика [Sravnitel'naya grammatika mongol'skogo pis'mennogo yazyka i khalkhaskogo narechiya: Vvedenie i fonetika]. Leningrad. 
Vovin 1995 - Vovin, Alexander. 1995. Reply to Karl Krippes concerning his review of Sergei Starostin's Altaiskaia Problema i Proiskhozhdenie iaponskogo iazyka [The Altaic Problem and the Japanese Language Origins]. Dhumbadji! 2(2): 25-32.

Vovin 2005 - Vovin, Alexander. 2005. The end of the Altaic controversy. Central Asiatic Journal 49(1): 71-132.

Vovin 2005-2009 - Vovin, Alexander. 2005-2009. A descriptive and comparative grammar of Western Old Japanese. Parts 1-2. Folkestone: Global Oriental.

Vovin 2009 - Vovin, Alexander. 2009. 'Japanese, Korean, and Other Non-Altaic Languages', a review article of Martine Robbeets. Is Japanese related to Korean, Tungusic, Mongolic, and Turkic? Central Asiatic Journal 53(1): 105-147.

Wohlgemuth 2009 - Wohlgemuth, Jan. 2009. A typology of verbal borrowings (Trends in Linguistics. Studies and Monographs 211). Berlin / New York: Mouton de Gruyter.

Zajączkowski 1934 - Zajączkowski A. 1934. Studia nad językiem staroosmańskim. Kraków.

\section{А. В. Дыбо. Новое в европейской алтаистике.}

Статья посвящена обсуждению текущих актуальных проблем алтайского исторического языкознания размышлениям, преимущественно завязанном на критической оценке двух больших монографий Мартины Роббеетс - об алтайском происхождении японского языка (Robbeets, Martine. 2005. Is Japanese related to Korean, Tungusic, Mongolic and Turkic? Wiesbaden: Harrassowitz) и о подтверждении алтайской гипотезы на материале сравнительной глагольной морфологии (Robbeets, Martine. 2015. Diachrony of verb morphology: Japanese and the Transeurasian Languages. Berlin: Mouton de Gruyter). Наряду с анализом основных методологических положений и отдельных этимологических решений М. Роббеетс на конкретном материале рассмотрен и подвергнут критике ряд тезисов, общих для антиалтаистического направления.

Ключевые слова: алтайские языки, историческая тюркология, глагольная морфология, дальнее родство языков, история японского языка, этимология. 